Prace Historyczno-Archiwalne t. XXXIII, Rzeszów 2021

ISSN: 1231-3335

\author{
Jacek Marian Hołub ${ }^{1}$ \\ ORCID 0000-0002-1437-2337 \\ DOI:10.30657/pha.33.2021.03 \\ (Uniwersytet Rzeszowski) \\ e-mail: jacekgopr@o2.pl
}

\title{
Garnizon wojskowy w Jarosławiu w latach 1782-1939
}

\section{Streszczenie}

Opracowanie dotyczy działalności wojska w garnizonie funkcjonującym w przestrzeni miejskiej Jarosławia w latach 1782-1939. Tematyka ta nie była dotąd przedmiotem zainteresowania historyków i badaczy dziejów Jarosławia. Zachowane szczątkowo źródła archiwalne, jak i materiały publicystyczne posłużyły do lokalizacji koszar, odtworzenia struktury organizacyjnej oddziałów i pododdziałów broni, składu osobowego koszar, działalności wojska w okresie pokoju i w stanie wojny, życia żołnierzy w koszarach, jak też współpracy z ludnością cywilną w Jarosławiu.

\section{Słowa kluczowe:}

garnizon wojskowy, wojska austriackie, wojsko polskie, Jarosław, okres autonomii galicyjskiej, okres międzywojenny.

\section{Wstęp}

Dematyka obecności wojska w przestrzeni miejskiej Jarosławia, w szczególności garnizonu wojskowego, nie była dotąd przedmiotem szerszych opracowań naukowych. Dotychczas ukazało się kilka opracowań publicystycznych, które są dość ogólne i niejednorodne. Dlatego poniższy artykuł, jest przyczynkiem do dalszych, gruntownych badań naukowych nad działalnością garnizonu wojskowego w Jarosławiu w latach 1782-1939.

1 Jacek Marian Hołub - jarosławianin, absolwent Uniwersytetu Rzeszowskiego, regionalista, przewodnik Stowarzyszenia Przewodników „Karpaty”, ratownik GOPR Grupa Bieszczadzka, autor i wydawca publikacji promujących zabytki Jarosławia i województwa podkarpackiego. W 2021 r. obronił rozprawę doktorską pt. Społeczność Jarosławia w latach 1918-1939. 
Opisywany okres obejmuje czas od powstania austriackiego garnizonu wojskowego, tj. dyslokowania pierwszych oddziałów austriackich w 1782 r., przyjęty przez autora jako data początkowa, natomiast datę końcową wyznacza opuszczenie przez wszystkie formacje wojskowe Garnizonu Jarosław podczas mobilizacji powszechnej przed wybuchem II wojny światowej, tj. 1 września 1939 r.

Celem pracy jest charakterystyka garnizonu wojskowego w Jarosławiu, tworzonego przez garnizon cesarsko-królewski i austriacki w latach 1782-1918, czwartego garnizonu w Galicji pod względem liczby żołnierzy, a następnie, w latach 1918-1939, garnizonu Wojska Polskiego, utworzonego po odzyskaniu niepodległości przez Polskę. Analiza obejmuje zagadnienia odnoszące się do struktury organizacyjnej obu tych garnizonów i współpracy ich załogi wojskowej z mieszkańcami Jarosławia, będącego częścią Monarchii Austro-Węgierskiej oraz Drugiej Rzeczypospolitej.

\section{Garnizon Cesarsko-Królewskiej Armii w latach 1782-1918}

Początek cesarsko-królewskiego garnizonu wojskowego w Jarosławiu wiąże się z pierwszym rozbiorem Rzeczypospolitej, dokonanym pod koniec XVIII wieku. Decyzje jednego z państw zaborczych - Austrii dotyczyły m.in. bezprawnej lokalizacji magazynów, urzędów i koszar dla wojska w zarekwirowanych budynkach klasztornych na terenie miasta.

W Jarosławiu zaborca austriacki zajął dla potrzeb wojska opuszczone obiekty skasowanego w 1773 r. zakonu Towarzystwa Jezusowego - Jezuitów. W pojezuickim, czworobocznym budynku kolegium utworzono w 1782 r. magazyn (prowiantowy), a w kościele pw. św. Jana - koszary, które nazwano Klasztornymi (Kloster Kaserne) ${ }^{2}$. Koszary stały się zalążkiem austriackiego garnizonu wojskowego w Jarosławiu, który powiększano bez dłuższej perspektywy i planów.

Po zlikwidowaniu kolegiaty pw. Wszystkich Świętych w 1800 r. zwrócono katolikom pojezuicką świątynię, która stała się kościołem parafialnym i garnizonowym³ ${ }^{3}$ Od 1870 r. w budynku kolegium funkcjonowały warsztaty i magazyny Wojskowej Komisji Mundurowej, przeniesione ze wzgórza św. Mikołaja ${ }^{4}$, a w latach dziewięćdziesiątych XIX w. stacjonował tam 90. Pułk Piechoty Austro-Węgierski.

Opuszczone w 1773 r. przez zakonników jezuickie zamiejskie kolegium objęli w 1777 r. wraz z kościołem, za zgodą rządu austriackiego, ojcowie Dominikanie. W wydzielonej części klasztoru, przy braku miejsc lokalowych, władze wojskowe zakwaterowały żołnierzy austriackich oraz utworzyły szpital wojskowy ${ }^{5}$. W 1882 r. jedno z pomieszczeń oficyn klasztornych przeznaczone zostało dla wozów bojowych ${ }^{6}$.

2 M. Orłowicz, Jarosław, jego przeszłość i zabytki, Lwów-Warszawa 1921, s. 60; Jarosławskie drogi do niepodległości, red. Ł. Zagrobelny, Jarosław 2018, s. 16.

3 M. Orłowicz, Jarosław, jego przeszłość..., s. 97; A. Wondaś, Szkice do dziejów Jarosławia, t. 1, Jarosław 1934, s. 46, 126.

4 M. Orłowicz, Jarosław, jego przeszłość..., s. 69; Jarosławskie drogi do niepodległości..., s. 16.

5 J.M. Hołub, Wzgórze Pobożności. Sanktuarium Matki Bożej Bolesnej w Jarosławiu, Jarosław 2017, s. 36.

6 Jarosławskie drogi do niepodległości..., s. 21. 
Na mocy dekretu kasacyjnego, wydanego przez cesarza Austrii Józefa II, skasowany został 6 września 1782 r. klasztor panien Benedyktynek w Jarosławiu. Zakonnice w ciągu pół roku musiały opuścić położone na wzgórzu św. Mikołaja warowne opactwo, pozostawiając cały majątek, natomiast kościół przyklasztorny pw. św. Mikołaja i Stanisława, na mocy kolejnego dekretu cesarskiego, został zamknięty dla wiernych 15 listopada 1783 r. Zaborca austriacki, po sprzedaniu majątku ruchomego i wszelkich dóbr zakonnych, zajął opuszczone przez siostry obiekty. Zabudowania klasztorne przeznaczone zostały w 1784 r. na warsztaty Wojskowej Komisji Mundurowej $^{7}$, natomiast budynek świątyni zamieniono na wojskowy magazyn ${ }^{8}$. W $1870 \mathrm{r}$., po zlikwidowaniu warsztatów Komisji Mundurowej ${ }^{9}$, które przeniesiono na sąsiednie Wzgórze św. Jana ${ }^{10}$, wojsko austriackie zajęło pobenedyktyńskie obiekty na koszary dla artylerii, nadając im nazwę Anna Kaserne - Koszary Anny ${ }^{11}$. W piętrowym budynku poklasztornym mogło pomieścić się około 320 żołnierzy ${ }^{12}$. W budynku kościoła urządzono skład siana i słomy, w innych obiektach szpital dla koni, kuźnię, pralnię i kuchnię ${ }^{13}$ Całość przestrzeni dawnego założenia opactwa, obwiedziona murami obronnymi z basztami, stanowiła przemyślana kompozycja układu wewnętrznego, którego oś główną tworzyła droga od bramy wjezdnej, łącząca mniejsze drogi komunikacyjne ${ }^{14}$. Na terenie koszar znajdowała się studnia, plac ćwiczeń, ujeżdżalnia, strażnica w baszcie bramnej, a w innych basztach magazyny amunicji oraz zboża ${ }^{15}$. Tak zagospodarowany obiekt był istotnym elementem i znakomitym zapleczem dla potrzeb garnizonu wojskowego. Koszary Anny na wzgórzu św. Mikołaja połączono mostem z koszarami Klasztornymi na wzgórzu św. Jana.

W Koszarach Anny stacjonowały dwie kompanie piechoty oraz sztab batalionu 90. Pułku Piechoty Austro-Węgier, a w latach siedemdziesiątyh XIX w. - 10. Dywizjon Artylerii Konnej ${ }^{16}$. Władze wojskowe nosiły się z zamiarem, aby w ramach przeprowadzanych remontów obiektów koszarowych przekształcić w przyszłości pobenedyktyńską świątynię w kościół garnizonowy lub szkolny, ale wybuch I wojny światowej zniweczył te plany ${ }^{17}$.

Zajmowanie na cele wojskowe obiektów klasztornych po skasowanych zakonach było zjawiskiem charakterystycznym dla tego okresu i posunięciem najbardziej

7 M. Orłowicz, Jarosław, jego przeszłość..., s. 60; A. Wondaś, Szkice do dziejów Jarosławia. Szkic uzupełniający. Jarosław w pierwszych latach ery samorzq̨dowej 1867-1889, Jarosław 1938, s. 45.

8 J. Stęchły, Zagospodarowanie przestrzenne Wzgórza Świętego Mikołaja w Jarosławiu w latach 1782-1914, „Ochrona Zabytków” 2013, r. LXVI, nr 1-4 (260-263), s. 88.

9 M. Orłowicz, Jarosław, jego przeszłość..., s. 69.

10 Jarosławskie drogi do niepodległości..., s. 16; J. Stęchły, Zagospodarowanie przestrzenne Wzgórza..., s. 89.

11 Nazwa koszar nawiązuje do księżnej Anny Ostrogskiej, która ufundowała zespół klasztorny Panien Benedyktynek. Patrz: J. Hołub, Dawne Opactwo PP. Benedyktynek. Ośrodek Kultury i Formacji Chrześcijańskiej w Jarosławiu, Jarosław 1999, s. 9-11; Jarosławskie drogi do niepodległości..., s. 17.

12 J. Stęchły, Zagospodarowanie przestrzenne Wzgórza..., s. 91.

13 M. Orłowicz, Jarosław, jego przeszłość..., s. 108.

14 Zob.: Plan katastralny miasta z 1849 r., Plan sytuacyjny koszar z 1883 r., z 1890 r.

15 J. Stęchły, Zagospodarowanie przestrzenne Wzgórza..., s. 89.

16 Jarosławskie drogi do niepodległości..., s. 17.

17 M. Orłowicz, Jarosław, jego przeszłość..., s. 109-110. 
„ekonomicznym”. W ramach zaspokajania potrzeb lokalowych wojska austriackiego oraz powiększenia tworzonego w Jarosławiu garnizonu, podobny los spotkał założenie dawnej rezydencji biskupów przemyskich w Radymnie ${ }^{18}$. W ogrodach rezydencji wybudowane zostały koszary dla 9. Pułku Piechoty oraz koszary kawalerii, gdzie stacjonował 8. Pułk Dragonów i 11. Pułk Ułanów.

Według ks. Franciszka Siarczyńskiego, proboszcza parafii pw. Bożego Ciała w Jarosławiu, powołującego się na spis ludności z 1813 r., załoga wojskowa w Jarosławiu liczyła 650 żołnierzy ${ }^{19}$. Rosnąca liczba żołnierzy i oddziałów w garnizonie jarosławskim wiązała się z sytuacją polityczną kraju, pojemnością nowych koszar oraz możliwościami mobilizacyjnymi Wojskowej Komisji Uzupełnień. Przy braku odpowiednich miejsc koszarowych dla dyslokowanych nowych formacji wojskowych w Jarosławiu, władze austriackie podjęły decyzję o dzierżawie niektórych realności i obiektów murowanych od osób prywatnych w mieście, tworząc tam koszary doraźne.

W pierwszej połowie XIX w. we wschodniej części miasta, na Podzamczu, dyslokowano koszary dla kawalerii zwane Koszarami Robinsona ${ }^{20}$; nazwa odnosiła się do właściciela kilku murowanych budynków przy obecnej ul. Podzamcze 37. Kompleks, wynajęty w 1879 r. od właściciela przez Skarb Wojskowy, obejmował murowany dwukondygnacyjny budynek oraz magazyny i zabudowania stajenne dla koni kawalerii ${ }^{21}$. W koszarach stacjonował 90. Pułk Piechoty do 1907 r.

Na przedmieściu Blich (obecne ulice: Na Blichu i Blichowa) dyslokowano koszary dla piechoty o nazwie Koszary Pfeffera - od nazwiska właściciela kilku obiektów murowanych, Abrahama Pfeffera. W 1881 r. w koszarach tych stacjonował szwadron 8. Pułku Huzarów (Kaserne des K.u.k. Dragonerregiments Nr. 8).

Na Przedmieściu Krakowskim (obecnie ul. Brzostków), gdzie dla oddziału kawalerii władze wojskowe wynajęły kilka obiektów murowanych od właściciela realności i przedsiębiorcy budowlanego Leopolda Goldfingera, usytuowano tzw. Koszary Goldfingera ${ }^{22}$. Oddział kawalerii stacjonował tam do końca XIX w., a następnie, po bankructwie właściciela, dzierżawione obiekty przejęte zostały przez Galicyjski Bank Hipoteczny we Lwowie ${ }^{23}$.

W latach pięćdziesiątych XIX w. właściciel realności na Przedmieściu Krakowskim, Karol Dietzius, wybudował wolno stojący budynek koszarowy. Posadowiony w ogrodach tej części miasta, wszedł on w obszar budowanych tam koszar, które na-

18 Z. Bielanowicz, Rezydencja biskupów przemyskich w Radymnie, „Rocznik Stowarzyszenia Miłośników Jarosławia”, t. XI, 1984-1985, Jarosław 1986, s. 172.

19 F. Siarczyński, Wiadomość historyczna i statystyczna o mieście Jarosławiu położonem w Królestwie Galicyi, w Cyrkule Przemyskim, niegdyś w Województwie Ruskim, ziemi Przemyskiey, domu JJ. 00. Xsiążąt Czartoryskich dziedzicznem, Lwów 1826, s. 141; J. Białynia, J. Chołodecki, Kilka szczegółów z przeszłości miasta Jarosławia, „Rocznik Stowarzyszenia Miłośników Jarosławia", t. XII, 1986-1993, Jarosław 1994, s. 101-103.

20 K. Kieferling, Garnizon Jarosławski do 1914 r., [w:] 100 rocznica wybuchu I wojny światowej $w$ artyleryjskim Garnizonie Jarosław. Historia, doświadczenie i rozwój artylerii do działań w środowisku górskim, red. G. Bechta, S. Nabywaniec, S. Skupień, Rzeszów 2014, s. 104.

21 Do dnia dzisiejszego zachował się dwukondygnacyjny obiekt przy ul. Podzamcze 37. Pozostałe obiekty, tj. budynki stajenne i magazyny konnicy uległy rozbiórce.

22 Obecnie tylko w części dawnych koszar Goldfingera funkcjonuje kilka obiektów, pełniąc różne funkcje, m.in. lokali mieszkalnych, usługowych oraz magazynu.

23 K. Kieferling, Garnizon Jarosławski do 1914 r., [w:] 100 rocznica wybuchu..., s. 103. 
zwano Koszarami Dietziusa ${ }^{24}$. W latach osiemdziesiątych XIX w. w budynku mieściła się kancelaria Komendy Uzupełniającej 90. Pułku Piechoty ${ }^{25}$. Pod koniec XIX w. Skarb Wojskowy przejął gmach i - po rozbudowaniu o dwa segmenty boczne - przeznaczono go na Kasyno Garnizonu. W tej postaci służył na potrzeby całego garnizonu i stanowił główny ośrodek życia społeczno-kulturalnego Jarosławia. Znajdowała się tam reprezentacyjna sala teatralna i widowiskowa, kawiarnia i cukiernia oraz elegancka restauracja - restauratora E.F. Johna ${ }^{26}$. Frontowe wejście do kasyna usytuowane było przy obecnej ul. Grunwaldzkiej 9.

Utworzony w Jarosławiu garnizon wojskowy był stosunkowo niewielkim zgrupowaniem dyslokowanych tam różnych formacji wojskowych, tj. piechoty, kawalerii i artylerii. Perspektywa rozbudowy garnizonu w bliskiej przyszłości była jednak sprawą oczywistą, ze względu na politykę bezpieczeństwa prowadzoną przez władze państwa austriackiego w drugiej połowie XIX stulecia.

\section{Powiększenie garnizonu}

Rozbudowa austro-węgierskiego garnizonu wojskowego w Jarosławiu w drugiej połowie XIX w. nastąpiła po pogorszeniu się stosunków między Austrią i Rosją, a miała istotny związek z ostateczną decyzją władz austriackich, po wytypowaniu Przemyśla jako miasta przeznaczonego na austriacką twierdzę I klasy. Chociaż Jarosław też dysponował przekonującymi argumentami na rzecz takiej inwestycji, które przedstawił minister wojny, generał Franz Kuhn, to przeważająca liczba „wpływowych” głosów zmieniła decyzję na negatywną. Miasto Jarosław musiało w tej sytuacji pełnić rolę obwarowanego przyczółka mostowego. Dlatego konieczne było znaczne powiększenie garnizonu wojskowego, który tworzyło kilkanaście oddziałów różnych formacji wojskowych w koszarach piechoty, artylerii i kawalerii, w zajętych obiektach założeń klasztornych oraz innych, dzierżawionych jako koszary doraźne.

Według Mieczysława Orłowicza:

„[...] Jarosław posiadał wielki garnizon, w skład, którego wchodziły cztery pułki piechoty, dwa artylerii, jeden kawalerii i kilka batalionów wojsk technicznych, sanitarnych i artylerii fortecznej. Żołnierze piechoty, rekrutowani z Galicji, byli to przeważnie Polacy i Rusini, kawaleria natomiast składała się zazwyczaj z czeskich dragonów i węgierskich huzarów, przy artylerii i wojskach pomocniczych służyli Niemcy, a w korpusie oficerskim, złożonym z kilkuset oficerów, spotkać było można wszystkie narodowości Austrii, z wielkq przewagą Niemców, a z wyjątkiem Polaków i Rusinów, których z zasady nie przydzielano do garnizonów galicyjskich. [...]”27.

W drugiej połowie XIX w. poszerzono granice administracyjne miasta Jarosławia, co dało możliwość zagospodarowania perspektywicznego przedmieść. Ważne czynniki sprzyjające rozbudowie Jarosławia to:

${ }^{24}$ Nazwa koszar nawiązuje do Karola Dietziusa - ojca Adolfa Dietziusa, burmistrza miasta Jarosławia. Z. Kostka-Bieńkowska, Jarosławskie CORSO. Historia ulicy Grunwaldzkiej i Krakowskiej, Jarosław 2016, s. 35.

25 Ibidem, s. 13.

26 Ibidem, s. 34.

27 M. Orłowicz, Moje wspomnienia turystyczne, Wrocław-Warszawa-Kraków 1970, s. 28. 
1. doprowadzenie w 1857 r. linii kolei żelaznej im. Arcyksięcia Karola Ludwika z Krakowa i Wiednia, a w kolejnych latach przedłużenie jej do Lwowa oraz wybudowanie drugiej linii do Sokala ${ }^{28}$;

2. ostateczna decyzja władz austriackich z 1871 r. w sprawie przydzielenia miastu funkcji wspomagającej i magazynowej na rzecz budowy twierdzy I klasy w Przemyślu;

3. rozbudowa garnizonu wojskowego od 1881 r., w tym koszar dla różnych formacji wojskowych, finansowana przez Austriackie Ministerstwo Wojny i Gminę Miejską w Jarosławiu.

Po Kongresie berlińskim w 1878 r. władze austriackie, w ramach polityki obronności kraju, sukcesywnie powiększyły wszystkie garnizony w Galicji. W Jarosławiu m.in. zwiększano stan osobowy wielonarodowej grupy żołnierzy oraz kadry oficerskiej, dyslokując tam nowe formacje wojskowe piechoty, kawalerii i artylerii. Dla oficerów wynajmowano kwatery w prywatnych budynkach, a dla jednostek wojskowych - prywatne obiekty na składy magazynowe i stajnie dla koni.

Dzięki zaangażowaniu władz miejskich powstał na terenie miasta system dróg i chodników, wybudowano rzeźnię, targowicę i sieć szkół. Do ważnych inwestycji należy zaliczyć obiekty wojskowe na terenach przeznaczonych pod koszary. Generalnie budynki koszarowe były projektami sztampowymi dostarczanymi przez wojskowe biura projektowe. Budynki w większości były murowane, do dwóch pięter, o skromnych, neoklasycystycznych formach, dostosowane do specyfiki konkretnych komend i jednostek wojskowych. Budowa koszar generalnie finansowana była przez rząd austriacki, w części przez Gminę Miejską Jarosław, która deklarowała taką formę rozbudowy miasta w zamian za pożyczkę bezprocentową ${ }^{29}$. Dodatkową korzyścią dla lokalnej społeczności była okoliczność, że koszary mógł budować inwestor prywatny, który uzyskał zgodę władz wojskowych na taką budowę. Na przykład, inwestor i przedsiębiorca budowlany Antoni Fleischl z Wiednia wybudował koszary dla kawalerii na Lachmanówce, a Leopold Goldfinger - budynek przeznaczony na potrzeby kwaterunku dla wojska (obecnie siedziba Starostwa Powiatowego w Jarosławiu). Na zapleczu obiektu postawiono budynki stajenne, wozownię oraz siodlarnię wojskową ${ }^{30}$.

Dla potrzeb rozrastającego się garnizonu wojskowego budowano na przedmieściach Jarosławia kompleksy koszarowe, a w nich budynki mieszkalne dla oficerów, magazyny sprzętowe i żywnościowe, rampy rozładowcze, maneże, ujeżdżalnie oraz strzelnice. Nieocenionym źródłem dla badaczy tematyki militarnej jest Plan Jarosławia, wykonany przez inż. S. Kornmana w skali 1:14 400, prezentujący m.in. dyslokację wojskowych koszar oraz obiektów garnizonowych w 1906 r. Koszary mieściły się przy ulicach: Benedyktyńskiej, Brzostkowiu, Czarnieckiego, Jezuickiej, Krakowskiej, Kościuszki, Koszarowej, Poniatowskiego, Piekarskiej i 3 Maja oraz Na blichu i Na Pozamczu.

28 A. Wondaś, Szkice do dziejów Jarosławia. Szkic uzupełniający..., s. 45, 82; Jarosławskie drogi..., s. 14-15.

29 M. Gosztyła, B. Jagieła, I. Dudzik, Architektura Galicji w dobie autonomii na przykładzie Jarosławia, Rzeszów 2013, s. 170.

30 Z. Kostka-Bieńkowska, Jarosławskie CORSO..., s. 30. 
W latach 1881-1897, na tzw. Gergoncie ${ }^{31}$ przy ul. Koszarowej (obecnie ul. Księcia Józefa Poniatowskiego), wybudowano koszary dla piechoty, tzw. miejskie, którym nadano imię Cesarza Franciszka Józefa I. Inwestorem kompleksu, składającego się z kilku budynków jedno- i dwupiętrowych, była Gmina Miejska w Jarosławiu, a budowę nadzorował architekt miejski inż. Stanisław Rutkowski.

Na terenie Lachmanówki (obecne Osiedle Wojska Polskiego) powstały w latach 1909-1910 koszary dla kawalerii (Lager des K.u.k. Regiments Nr. 89), w których stacjonował węgierski pułk huzarów. Inwestorem był wiedeńczyk Antoni Fleischl, który uzyskał zezwolenie na budowę od władz wojskowych, gdy hr. Stanisław Siemieński-Lewicki sprzedał mu znaczny obszar ziemi. Gmina Miejska w Jarosławiu miała spłacić tę inwestycję w ciągu 25 lat. W skład kompleksu koszar wchodziło kilkanaście budynków jedno- i dwupiętrowych, różnorodnych pod względem architektury i przeznaczenia. Były tam budynki reprezentacyjne, mieszkalnia dla oficerów i podoficerów oraz kasyno oficerskie, usytuowane frontem do obecnej ul. Poniatowskiego. Na zapleczu znajdował się plac ćwiczeń, ujeżdżalnia, pralnia, budynki stajenne i magazyny ${ }^{32}$.

W latach 1887-1888 wybudowane zostały przy ul. Pruchnickiej koszary dla piechoty (Baracken Lager Nr. 1), zwane Koszarami Skarbowymi lub Rządowymi (Baraki $\mathrm{Nr} 1)^{33}$. Kompleks koszarowy składał się z kilkunastu budynków mieszkalnych, pomieszczeń sztabu, placu ćwiczeń, magazynów i warsztatów, a w centrum był plac apelowy. W koszarach stacjonował 89. Galicyjski Pułk Piechoty hrabiego von Albori ${ }^{34}$.

Na Przedmieściu Głębockim, w bliskości dawnego folwarku pojezuickiego, wybudowano w latach 1887-1897 kompleks koszar dla artylerii (Baraki Nr 2). W 1906 r. powiększono kompleks koszarowy wzdłuż ul. 3 Maja (prawa strona), budując parterowe budynki mieszkalne dla wojska, plac alarmowy, magazyny i warsztaty. Do 1914 r. w koszarach stacjonował 29. Pułk Armat Polowych ${ }^{35}$.

Na Przedmieściu Krakowskim, przy granicy założenia klasztornego oo. Franciszkanów-Reformatów, wybudowane zostały przez Gminę Miejską w Jarosławiu tzw. Koszary Miejskie (Baraki Nr 3, zwane „Obozem szwedzkim”36). W koszarach usytuowano parami, w formie obozu, 23 budynki parterowe i jednopiętrowe, w których stacjonowały trzy pułki piechoty: 34., 89. i 90.

Niedaleko od nich, po drugiej stronie obecnej ul. Jana Pawła II, wybudowano w latach 1886-1887, również z inicjatywy jarosławskiej Gminy Miejskiej, koszary Obrony Krajowej Nr 58, zwane Miejskimi. Kompleks koszar, z jednopiętrowym budynkiem głównym, był budowany pod nadzorem architekta miejskiego, inż. Stanisława Rutkowskiego ${ }^{37}$.

31 Nazwa koszar nawiązuje do nazwiska dworzanina księżnej Anny Ostrogskiej (1575-1635), właścicielki Jarosławia.

32 Jarosławskie drogi do niepodległości..., s. 19-20.

33 Obecnie kampus Państwowej Wyższej Szkoły Techniczno-Ekonomicznej im. Ks. Bronisława Markiewicza przy ul. S. Czarnieckiego 16.

34 Jarosławskie drogi do niepodległości..., s. 20.

35 Pułk został sformowany 1 I 1894 r. jako 29. Pułk Artylerii Dywizyjnej. Pułk wchodził w skład 10. Brygady Artylerii Polowej Nr X Korpusu. Jednostka składała się z komendy, czterech baterii armat polowych $80 \mathrm{~mm}$ oraz baterii zapasowej.

36 Nazwa nawiązuje do symbolicznej formacji Króla Szwecji Fryderyka - założonej w XVIII wieku.

37 Jarosławskie drogi do niepodległości..., s. 19. 


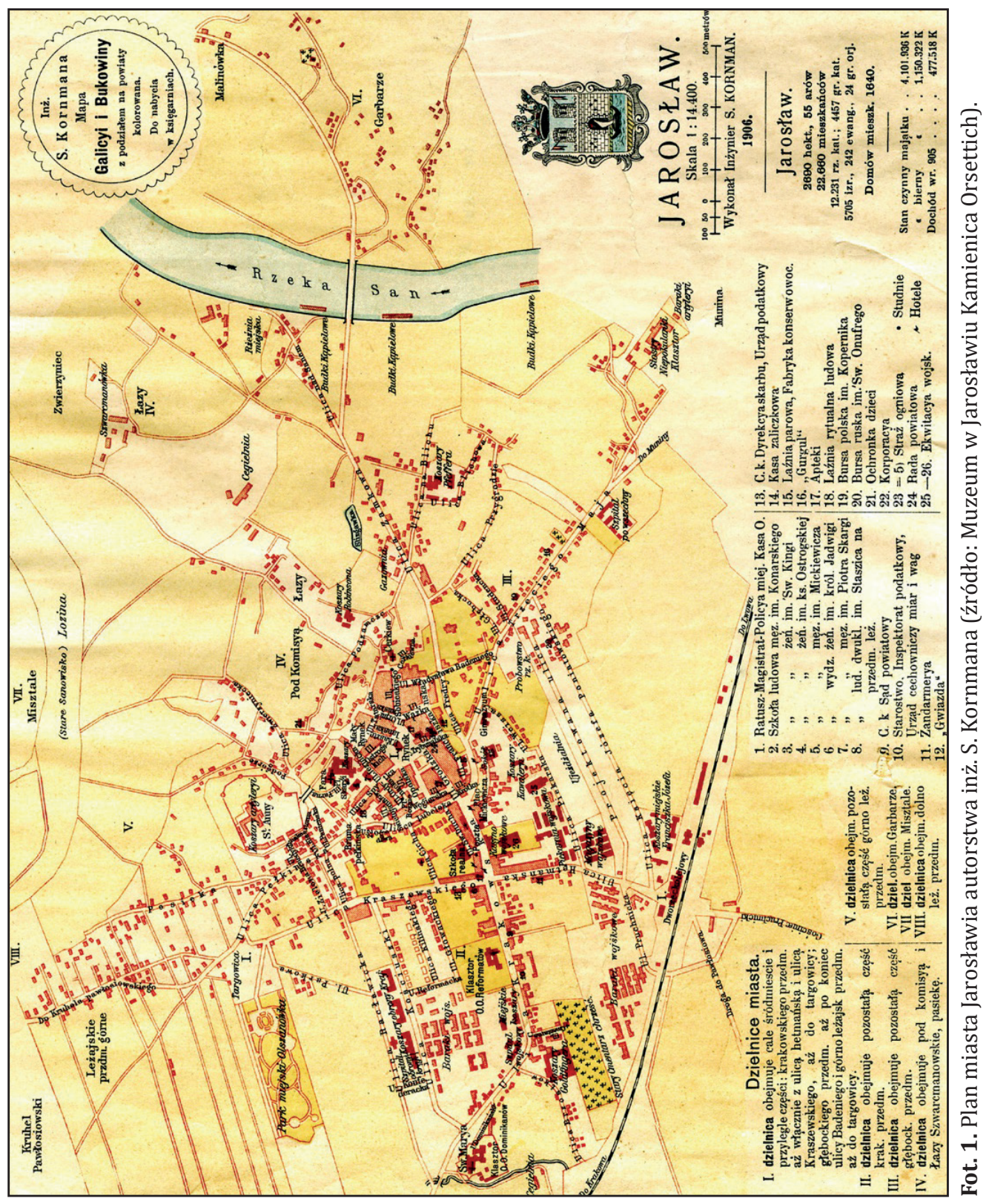


W 1892 r. w budynku głównym nadbudowano II piętro ${ }^{38}$. W jego pobliżu znajdował się dwupiętrowy gmach, z napisem na ścianie frontowej: Ferdinandus I Austriae Impperator $1844^{39}$, zaadaptowany w 1886 r. na szpital wojskowy.

Przy ul. Piekarskiej, w latach osiemdziesiątych XIX w., usytuowano magazyny żywnościowe (K.u.k. Verpflgs-Magazin). W koszarach funkcjonowała także piekarnia wojskowa, baraki dla pionierów konnicy technicznej oraz dwie halowe ujeżdżalnie z jednoprzęsłowymi wnętrzami i ujeżdżalnia na wolnym powietrzu. Koszary przy ul. Piekarskiej pod koniec XIX stulecia przyjęły nazwę: Koszary Kawalerii, a stacjonował w nich 8. Pułk Dragonów grafa Rajmunda Montecurolli ${ }^{40}$.

Przy ul. Kościuszki w latach 1900-1901 wybudowany został kompleks koszar Obrony Krajowej Nr 34 - K.u.k. Landwehr Kaserne Nr. 34. Początkowo było to kilka dwupiętrowych budynków, a w 1904 r. postawiono pawilon dla chorych od strony zachodniej (obecnie ul. Konfederacka) ${ }^{41}$.

Resumując, do 1914 r. w garnizonie w Jarosławiu stacjonowały następujące komendy: Komenda Dywizji Piechoty Nr 2, Komenda Dywizji Kawalerii Nr 6, Komenda Brygady Piechoty Nr 4, Komenda Brygady Kawalerii Nr 5, Komenda Stacji Obrony Krajowej, Komenda Brygady Obrony Krajowej, Komenda Uzupełniająca Obrony Krajowej 34. Pułku Piechoty, Komenda Powiatowa Pospolitego Ruszenia Nr 34, Komenda Oddziałowa Żandarmerii Nr 13, Komenda Powiatowa Żandarmerii, Wojskowa Komenda Stacji, Komenda Placu, Komenda Uzupełnień 90. Pułku Piechoty, Magazyn Zaopatrzenia, Filia Oddziału Wojskowego Budownictwa ${ }^{42}$ oraz oddziały i pododdziały broni: 1. Pułk Ułanów, 8. Pułk Dragonów, 10. Pułk Piechoty, 34. Pułk Piechoty (Landwehry), 40. Pułk Piechoty, 77. Pułk Piechoty, 89. Pułk Piechoty, 90. Pułk Piechoty, 29. Pułk Armat Polowych, 10. Dywizjon Artylerii Konnej ${ }^{43}$.

Dowódcami c.k. garnizonu w latach 1914-1918 byli: por. Siegmund von Benigni (1914), por. Franz Gross (1914-1915), gen. mjr Johann Schubert (1915 do 1 listopada 1918$)^{44}$.

Garnizon wojskowy - Militärische Garnison w Jarosławiu, należał do najliczniejszych garnizonów Galicji ${ }^{45}$. Pod względem liczby żołnierzy był czwartym po Lwowie, Krakowie i Przemyślu. Według ostatniego spisu ludności Monarchii Austro-Węgierskiej z 1910 r., w Jarosławiu stacjonowało 4422 żołnierzy ${ }^{46}$. Natomiast dane szacunkowe z pracy Mieczysława Orłowicza z 1914 r. wykazują, że w c.k. garnizonie służyło ok. 5000 żołnierzy ${ }^{47}$, a szacunki Andrzeja Wondasia mówią o ok.

38 Ibidem.

39 M. Orłowicz, Jarosław, jego przeszłość..., s. 121.

40 Jarosławskie drogi do niepodległości..., s. 19.

41 Ibidem, s. 20-21.

42 K. Kieferling, Krótka opowieść o mieście Jarosławiu w województwie podkarpackim leżącym, Jarosław 2011, s. 71.

43 Ibidem; A. Wondaś, Szkice do dziejów Jarosławia, t. II, Jarosław 1936, s. 123.

44 Ibidem, s. 126.

45 Z. Kostka-Bieńkowska, Monografia Stowarzyszenia Miłośników Jarosławia, Jarosław 2014, s. 11.

${ }^{46}$ Wiadomości statystyczne o stosunkach krajowych. Najważniejsze wyniki spisu ludności i zwierząt domowych według stanu z dn. 31 grudnia 1910 r., red. T. Pilat, t. XXIV, z. 1, Lwów 1911, s. 8, 14-15.

47 M. Orłowicz, Ilustrowany przewodnik po Galicji, Bukowinie, Spiszu, Orawie i Śląsku Cieszyńskim, Lwów 1914, s. 262. 
$4000^{48}$. Dla porównania, w garnizonie rzeszowskim stacjonowało wówczas 3357 żołnierzy, w łańcuckim - 400, natomiast w Garnizonie Tarnów - 2000 żołnierzy i oficerów ${ }^{49}$.

Liczba mieszkańców Jarosławia według danych spisu powszechnego ludności Galicji w 1910 r. wynosiła $24367^{50}$, natomiast w 1914 r. $-25000^{51}$.

Rozbudowa garnizonu wojskowego w Jarosławiu, oprócz realizowania polityki bezpieczeństwa państwa austriackiego, była czynnikiem miastotwórczym, który spowodował rozwój budownictwa indywidualnego i wzmocnienie gospodarki (handel, rzemiosło, usługi). Nowoczesny Jarosław przeniósł się poza mury miejskie, wzbogacając wytyczone dzielnice miasta o nowe obiekty koszarowe i budynki jednorodzinne oraz użyteczności publicznej. Miasto stało się istotnym węzłem kolejowym łączącym większe miasta w Galicji i dającym zatrudnienie znacznej liczbie mieszkańców. Powiększona załoga jarosławskiego garnizonu, skoszarowana w nowo wybudowanych obiektach, stała się dla miasta znaczącą grupą konsumentów oraz gwarantem bezpieczeństwa na wypadek wojny z Rosją.

\section{Garnizon w latach 1914-1918}

Wybuch wojny w lipcu 1914 r. spowodował, że uczniowie I Gimnazjum w Jarosławiu masowo wstępowali jako ochotnicy do Drużyn Strzeleckich i Drużyn Bartoszowych, z nadzieją zbrojnej walki o niepodległość. Młodzi ochotnicy, po stosownym kursie przygotowawczym, wymaszerowali pod komendą Serafina Dobrzańskiego ${ }^{52}$ do Krakowa, by walczyć w szeregach Legionów Polskich ${ }^{53}$.

48 A. Wondaś, Szkice do dziejów Jarosławia..., t. I, s. 38.

49 Jarosławskie drogi do niepodległości..., s. 28.

50 Wiadomości statystyczne o stosunkach krajowych..., s. 17; patrz: J.P. Zieliński, Nasza dola w Jarosławiu, Lwów 1914, s. 5; A. Wondaś, Szkice do dziejów Jarosławia..., t. I, s. 38; K. Zamorski, Informator statystyczny do dziejów społeczno-gospodarczych Galicji: ludność Galicji w latach 1857-1910, red. H. Mandurowicz-Urbańska, Kraków-Warszawa 1989, tabela XXV, s. 181.

51 M. Orłowicz, Ilustrowany przewodnik po Galicji.., s. 262.

52 Serafin Dobrzański - ur. 5 XII 1860 r. w Jarosławiu. Żołnierz armii austriackiej, urzędnik Starostwa Powiatowego w Jarosławiu. W 1914 r. twórca polskich wojskowych Drużyn Sokolich i dowódca 15. kompanii 2. Pułku Piechoty II Brygady Legionów. W 1918 r. komendant Straży Obywatelskiej w Jarosławiu. Kapitan Wojska Polskiego. Działacz społeczny: członek honorowy Towarzystwa Gimnastycznego „Sokół” i Związku Byłych Ochotników Armii Polskiej, członek Towarzystwa Rzemieślników „Gwiazda”, Koła Towarzystwa Szkół Ludowych, prezes Oddziału Związku Legionistów, przewodniczący Koła Związku Oficerów Rezerwy Rzeczypospolitej. Zmarł 18 XI 1936 r. w Jarosławiu, gdzie został pochowany na Starym Cmentarzu. Uchwałą Rady Miejskiej w Jarosławiu w 1936 r. jego imieniem nazwano boczną ulicę prowadzącą do ul. Kościuszki. Nazwa ulicy przetrwała do 1988 r. Jego nazwisko zostało umieszczone na tablicy pamiątkowej poświęconej X rocznicy wymarszu Drużyny Sokolej, wmurowanej w 1924 r. w ścianę gmachu dawnego Towarzystwa Gimnastycznego „Sokół” (obecnie Centrum Kultury i Sztuki).

53 A. Wondaś, Szkice do dziejów Jarosławia..., t. 2, s. 48; W. Jedliński, Młodzież Gimnazjum I. $w$ walkach o Niepodległość, [w:] Księga pamiątkowa poświęcona zjazdowi jubileuszowemu z okazji 50-lecia istnienia Gimnazjum I. w Jarosławiu 1884-1934, red. S. Kopystyński, A. Zych, Jarosław 1934, s. 149. 


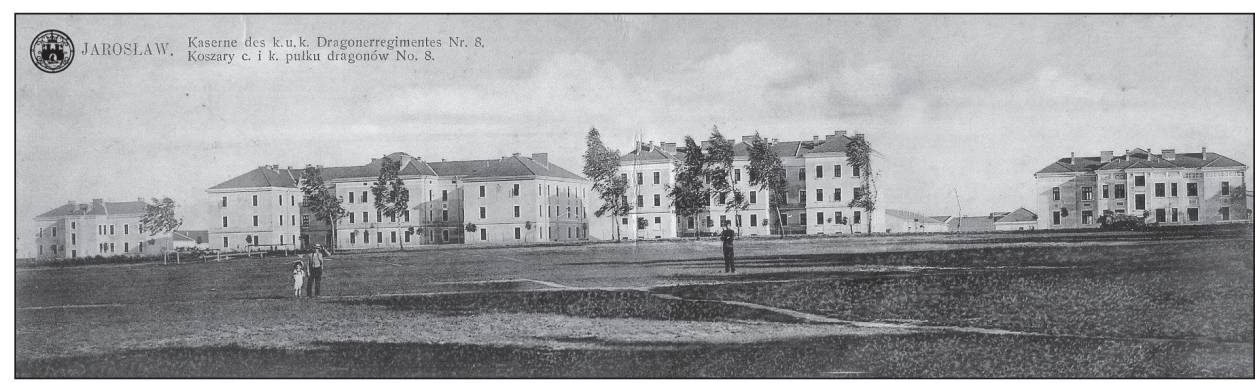

Fot. 2. Jarosław. Koszary C.K. Pułku Dragonów Nr 8 (źródło: Muzeum w Jarosławiu Kamienica Orsettich).

Jeszcze przed rozpoczęciem działań wojennych, w Monarchii Austro-Węgierskiej ogłoszono powszechną mobilizację mężczyzn, którzy wcieleni zostali do armii. Liczna załoga garnizonu w Jarosławiu, w tym oddziały piechoty, kawalerii i artylerii, po inwazji rosyjskiej we wrześniu 1914 r. opuściła miasto i zajęła wyznaczone miejsce na linii frontu. Na czas wojny w garnizonie zorganizowano szpitale zapasowe dla wojska w koszarach przy ul. Pruchnickiej i Poniatowskiego oraz w budynku szkoły im. Królowej Jadwigi. Dodatkowo uruchomiono szpital Czerwonego Krzyża w klasztorze Sióstr Niepokalanek ${ }^{54}$.

Wojska rosyjskie po krótkiej walce przekroczyły linię Sanu i 21 września 1914 r. wkroczyły do Jarosławia, przebywając w nim do 10 października. Komendantem miasta był pułkownik Władysław Koiszewski. Wojska austro-węgierskie po silnej kontrofensywie wyparły Rosjan za San. Po raz drugi Rosjanie pod dowództwem płk. Rużewa wkroczyli do miasta 5 listopada i pozostawały w nim do 16 maja $1915 \mathrm{r}^{55}$ Wielka ofensywa sprzymierzonych oddziałów austriackich i niemieckich, po przełamaniu frontu pod Gorlicami, toczyła boje pod Jarosławiem w dniach 13-15 maja, szczególnie zacięte w miejscowości Pawłosiów. Następstwem tych walk było kolejne wyparcie Rosjan z miasta ${ }^{56}$. Po odsunięciu się frontu wojennego, do koszar w jarosławskim garnizonie powróciły nieliczne oddziały i pododdziały różnych formacji wojskowych. Ciała poległych z obu armii grzebano w Jarosławiu na utworzonym specjalnie w tym celu cmentarzu wojskowym przy ul. Pruchnickiej oraz na cmentarzach komunalnych przy ul. Krakowskiej, Cmentarnej i Kraszewskiego.

W roku 1917 - trzecim roku wojny narastało dążenie Polaków do odzyskania niepodległości. Wydarzenia dziejowe obejmujące wszystkie mocarstwa zaborcze, w tym osłabienie linii frontu, pozwoliły na konspiracyjne zawiązanie Polskiej Organizacji Narodowej. Członkowie tej organizacji mocno wierzyli w wolność polityczną, dlatego m.in. w Jarosławiu śmiało manifestowali w lutym 1918 r. przeciw traktatowi brzeskiemu i kolejnym podziałom polskich ziem. Słabe państwo austro-węgierskie końcem października 1918 r. samoczynnie się rozpadło, co dało Polakom możliwość odzyskania po 123 latach upragnionej niepodległości i utworzenia suwerennego państwa.

54 Jarosławskie drogi do niepodległości..., s. 47.

55 W. Jedliński, Młodzież Gimnazjum I..., s. 152; K. Gottfried, Jarosław. Dzieje miasta od jego początków do 1939 roku, Jarosław 2019, s. 411.

56 M. Orłowicz, Jarosław, jego przeszłość..., s. 413. 


\section{Garnizon Jarosław Wojska Polskiego w latach 1918-1939}

Końcem października 1918 r. członkowie Polskiej Organizacji Narodowej w Jarosławiu przejęli władzę cywilno-wojskową w mieście ${ }^{57}$. Dowództwo nad jednostkami wojskowymi skoszarowanymi w Jarosławiu i Radymnie powierzono tymczasowo płk. Wiktorowi Jaroszowi ${ }^{58}$, natomiast stanowisko komendanta Garnizonu Jarosław - mjr. Aleksandrowi Krajewskiemu ${ }^{59}$, a następnie płk. Wiktorowi Jaroszowi ${ }^{60}$. W listopadzie 1918 r. garnizon objęło Wojsko Polskie. Komendantami Garnizonu Jarosław Wojska Polskiego byli kolejno: gen. brygady Franciszek Paulik, gen. brygady Jan Hempel, płk (od 1927 r. gen. brygady) Wacław Scaewola-Wieczorkiewicz ${ }^{61}$, płk dyplomowany Gustaw Paszkiewicz, gen. brygady Michał Pakosz, płk dypl. Bolesław Krzyżanowski, płk Bolesław Schwarzenberg-Czerny i kpt. Jan Gołdasz ${ }^{62}$.

Oddziały składające się w większości z polskich żołnierzy, stacjonujące w koszarach w Jarosławiu, w pierwszych dniach listopada 1918 r. skierowane zostały przez płk. Jarosza do obrony miast Galicji. Kompania złożona z członków POW z Jarosławia, pod dowództwem ppor. Władysława Kaszy, walczyła pod Medyką i Jaksmanicami oraz brała udział w odsieczy Lwowa. Oddział ochotników z Jarosławia wcielony

57 M. Pasterski, Działalność narodowa i niepodległościowa w Jarosławiu w latach 1900-1918, „Materiały i Studia Muzealne”, t. V, Przemyśl 1982, s. 89; M. Lisiński, Noc przełomowa z 31 X na 1 XI 1918 w Jarosławiu, Jarosław 1938, s. 6.

58 Wiktor Jarosz-Kamionka - ur. 21 X 1869 r. w Fałkowicach (województwo krakowskie). Żołnierz armii austriackiej. Za zasługi na polu walki nobilitowany z herbem Kamionka Mała. W 1918 r. awansowany na stopień pułkownika. W październiku 1918 r. objął tymczasowo dowództwo nad jednostkami wojskowymi w Garnizonie Jarosław. Od 1 XI 1919 r. do kwietnia 1920 r. dowodził utworzonym w Jarosławiu 1. Pułkiem Strzelców Ziemi Lwowskiej i Grupą Operacyjną w Małopolsce Wschodniej. W maju 1922 r. uzyskał stopień generała brygady. W 1927 r. przeszedł w stan spoczynku i osiadł we Wierzbnej k/Jarosławia. Zmarł 23 IX 1952 r. w Wierzbnej, gdzie został pochowany.

59 K. Skarbowski, Jarosław i Rok 1918, „Rocznik Stowarzyszenia Miłośników Jarosławia”, t. VII, 1967-1968, Jarosław 1968, s. 93-101; M. Pasterski, Działalność narodowa i niepodległościowa..., s. 86.

60 K. Skarbowski, Jarosław i Rok..., s. 98.

61 Wacław Wieczorkiewicz - ur. 25 VI 1890 r. w folwarku Brzozowa koło Puław. Od 1918 r. oficer Wojska Polskiego. Od czerwca 1926 r. do 25 X 1935 dowódca 24. Dywizji Piechoty i komendant Garnizonu Jarosław. 1 I 1927 r. awansowany do stopnia generała brygady. 7 XI 1931 r. za zgodą wojewody lwowskiego zmienił nazwisko rodowe na Scaewola-Wieczorkiewicz. Działacz społeczny w Jarosławiu: pierwszy prezes Oddziału Towarzystwa Ligi Morskiej i Kolonialnej, pierwszy prezes Towarzystwa Miłośników Starego Jarosławia, honorowy prezes Wojskowego Klubu Sportowego „Ognisko”. Jego imię nadano jarosławskiemu Oddziałowi Związku Strzeleckiego. Rada Miejska w Jarosławiu w 1935 r. nadała generałowi Honorowe Obywatelstwo Miasta Jarosławia. Zmarł 7 XII 1969 r. w Genewie. Uchwałą Rady Miejskiej w Jarosławiu w 1992 r. jego imię nadano ulicy na osiedlu Kolonia Oficerska, a w 2010 r. jego imię przyjął 14. Dywizjon Artylerii Samobieżnej w Jarosławiu. Patrz: J. Majka, Generał brygady Wacław Scaewola-Wieczorkiewicz 1890-1969. Krótka biografia wojskowa, Rzeszów 2018, s. 46; P. Stawecki, Słownik biograficzny generałów Wojska Polskiego 1918-1939, Warszawa 1994, s. 247-248; Dziennik Personalny nr 2 z dnia 26 stycznia 1934 r., k. 16; T. Skupień, Gen. bryg. Wacław Wieczorkiewicz patron 14 DAS, [w:] Służba wojskowa w garnizonach jarosławskim i przemyskim „wczoraj i dziś”, red. G. Bechta, S. Nabywaniec, T. Skupień, Rzeszów 2016, s. 112.

62100 rocznica wybuchu..., s. 62. 
został czasowo do 4. Pułku Piechoty Legionów. Pod koniec listopada kolejny oddział ochotników pod dowództwem płk. Wiktora Jarosza wymaszerował z koszar w Jarosławiu przeciwko ukraińskim wojskom znajdującym się po prawej stronie rzeki San, a następnie udał się w kierunku Krakowca i Jaworowa.

Pierwszym oddziałem bojowym sformowanym we Lwowie był 39. Pułk Piechoty, który jako I Batalion Zapasowy skierowany został do Jarosławia. Pozostałe bataliony pułku skierowano do walk na wschodzie, najpierw z Ukraińcami, potem z wojskami sowieckimi. Walki prowadzone z Ukraińcami i Sowietami zakończyły się w 1921 r., co dało możliwość ustalenia granic Drugiej Rzeczypospolitej.

\section{Struktura organizacyjna garnizonu}

W pierwszych latach po odzyskaniu niepodległości struktura organizacyjna Garnizonu Jarosław była zróżnicowana i oparta na wzorcach armii zaborczej. Według danych Ministerstwa Spraw Wojskowych, od 1921 r. funkcjonowały w Jarosławiu następujące komendy: Komenda Placu, Powiatowa Komenda Uzupełnień, Komenda Garnizonu, Komenda Uzupełnień Koni oraz Komenda Dworca ${ }^{63}$. W ramach reorganizacji armii Wojska Polskiego formowano i dyslokowano w latach 1921-1939 nowe jednostki w jarosławskim garnizonie: 3. Pułk Piechoty Legionów, 39. Pułk Piechoty Strzelców Lwowskich, 24. Pułk Artylerii Lekkiej im. Króla Jana III Sobieskiego, 2. Pułk Łączności, 6. Batalion Telegraficzny, Stacja psów meldunkowych, Dywizyjna Szkoła Podchorążych Rezerwy 24. Dywizji Piechoty, 10. Zapas młodych koni, 10. Dywizjon Artylerii Konnej, Pluton Żandarmerii, Dowództwo 24. Dywizji Piechoty, Służba remontu koni, Służba intendentury, Służba duszpasterska oraz Wojskowy Sąd Rejonowy Jarosław. Dodatkowo funkcjonowały: Strzelnica garnizonowa Szczytna i Widna, Plac ćwiczeń Makowisko, Kasyno Garnizonowe (oficerskie), kilka kasyn podoficerskich (pułkowych), Dom Żołnierza, Garnizonowa Izba Chorych oraz Szpital Wojskowy ${ }^{64}$.

\section{Parafie wojskowe w garnizonie}

W 1925 r., dzięki podpisaniu konkordatu ze Stolicą Apostolską, uregulowano status wojskowych parafii garnizonowych ${ }^{65}$. W Jarosławiu erygowano 1 maja 1926 r. katolicką wojskową parafię obrządku łacińskiego pw. św. Wojciecha biskupa męczennika ${ }^{66}$ oraz w 1927 r. parafię obrządku greckokatolickiego pw. św. Cyryla i św. Me-

63 WBH, CAW, sygn. I. 303.3.129, Wykaz Garnizonów na terenie podległym M. S. Wojsk. Ze stanu z dnia 1-go lutego 1921 roku, k. 29.

64 WBH, CAW, sygn. I. 372, 21, Komendy Garnizonów 1918-1939, K. Kieferling, Krótka opowieść o mieście..., s. 71; W. Sobocki, Jednostki Garnizonu WP Jarosław, „Rocznik Stowarzyszenia Miłośników Jarosławia", t. XII, 1986-1993, Jarosław 1994, s. 161-170.

${ }^{65}$ Konkordat pomiędzy Stolica Apostolskq a Rzeczq̨ospolita Polskq, podpisany w Rzymie dnia 10 lutego 1925 r. ratyfikowany zgodnie z ustawa z dnia 23 kwietnia 1925 r. (Dz.U. RP z 1925 r., Nr 47, poz. 324, Nr 72, poz. 501). J. Odziemkowski, S. Frątczak, Polskie duszpasterstwo wojskowe, Warszawa 1996, s. 116; G. Bechta, Konferencja-Jarosław 24.06.2015 r., [w:] Służba wojskowa w garnizonach..., s. 78-79.

${ }^{66}$ Parafie wojskowe, „Kronika Diecezji Przemyskiej” 1927, nr 2, s. 67; H. Borcz, Dekanat Jarosławski w II Rzeczypospolitej i w latach II wojny światowej (1918-1945), [w:] Sługa Boży ksiądz Stanisław Sudoł, zwiastun pojednania i dobroci, red. J. Konefał, Sandomierz 2015, s. 74. 
todego ${ }^{67}$. Funkcję kapelanów Garnizonu Jarosław sprawowali: dla katolików - dominikanin o. Dionizy Szpunarowicz ${ }^{68}$, ks. Mieczysław Lisiński, ks. kpt. Walenty Pączek ${ }^{69}$, ks. mjr Jan Ziółkowski, dla grekokatolików - ks. Cyprian Chotyniecki, dla wyznawców religii mojżeszowej - rabin Izaak Steinberg oraz dla ewangelików - ks. Karl Schick ${ }^{70}$.

Garnizon Jarosław Wojska Polskiego w pierwszych latach niepodległości zasilali w większości żołnierze deklarujący wyznanie katolickie, następnie mojżeszowe, ewangelickie i inne ${ }^{71}$. Kościołem garnizonowym parafii rzymskokatolickiej dla powiatów Jarosław, Przeworsk i Cieszanów został urzędowo wyznaczony kościół pw. Bożego Ciała ${ }^{72}$. Funkcję proboszcza parafii wojskowej pełnili kolejno: ks. kpt. Walenty Pączek oraz ks. kpt. Jan Ziółkowski. W parafii wojskowej obrządku łacińskiego w 1931 r. sakrament chrztu przyjęło 148 osób, sakrament małżeństwa 72 osoby, zmarło 47 osób $^{73}$. Proboszcz parafii wojskowej miał prawo udzielania sakramentu chrztu, małżeństwa, namaszczenia chorych oraz dokonywania obrzędów pogrzebowych.

Dostępne źródła informują o złożeniu wyznania wiary i przyjęciu do Kościoła katolickiego obrządku łacińskiego dwóch żołnierzy wyznania prawosławnego. Obaj żołnierze, po uzyskaniu zezwolenia przez Polową Kurię Biskupią w Warszawie, stali się konwertytami. Na przykład, złożenie wyznania wiary przez neofitę, sierżanta 3. Pułku Piechoty Legionów, odbyło się 30 listopada 1929 r. w obecności proboszcza ks. kpt. Walentego Pączka oraz dwóch świadków ${ }^{74}$. Drugi przypadek dotyczył plutonowego 39. Pułku Piechoty Legionów, który złożył wyznanie wiary 21 marca 1932 r. w obecności administratora parafii wojskowej ks. kpt. Pączka oraz dwóch świadków ${ }^{75}$. Do Kościoła katolickiego obrządku łacińskiego zostało 25 lutego 1938 r. przyjęte także małżeństwo wyznania mojżeszowego (małżonek był żołnierzem zawodowym w stopniu plutonowego). Obrzęd przyjęcia sakramentu chrztu przez neofitów odbył się w kaplicy Sióstr Felicjanek w Jarosławiu, a udzielił go ks. mjr Jan Ziółkowski" ${ }^{76}$.

67 P. Stawecki, Wojsko Marszałka Józefa Piłsudskiego 12 V 1926 - 12 V 1935, Warszawa 2004, s. 220, 222; J. Odziemkowski, S. Frątczak, Polskie duszpasterstwo..., s. 116.

68 J. Csàdek, „Z wojny narodowej 1918-1920 r.”. Wspomnienia z niektórych walk i przeżyć 14-go jarosławskiego pułku piechoty względnie 4-tej dywizji piechoty, t. I, Lwów 1935, s. 17.

69 Walenty Pączek - kpt. Wojska Polskiego. Kapelan Garnizonu Jarosław i proboszcz parafii wojskowej pw. św. Wojciecha Biskupa i Męczennika w Jarosławiu. W 1937 r. przeniesiony służbowo do Grodna. Patrz: WBH, CAW, sygn. I. 300.7.199, Rozkaz wewnętrzny Nr 5 z 15 III 1927, b.p.; J. Hołub, Kościół św. Ducha w Jarosławiu, Jarosław 2007, s. 59.

70 MwJKO, sygn. 76 a, Akta Ewangelickiego Urzędu Parafialnego w Jarosławiu. Gemeinde Buck von Jaroslau 1884-1939, b.p.

71 WBH, CAW, sygn. I. 300.20. Biuro Wyznań Niekatolickich 1919-1939; sygn. I. 300.20.99, Biuro Wyznań Niekatolickich Ministerstwo Wyznań Religijnych; sygn. I. 304.1.52. Komisja przeglądowa, pow. „Jarosław", [dok. b.p.].

72 Parafie Wojskowe, „Rocznik Diecezji Przemyskiej ob. łac.” 1938, Przemyśl 1938, s. 167; S. Zych, Diecezja Przemyska obrządku łacińskiego w latach 1939-1944/1945, Przemyśl 2011, s. 157.

73 Ruch ludności parafii jarosławskiej o. ł. w roku 1931, „Jarosławskie Wiadomości Parafialne” 1932, nr 5, s. 7.

74 APBCwJ, Księga nawróconych (Liber Convesonium) Parafii Wojskowej rok 1938, k. 1, poz. 1.

75 Ibidem, k. 2, poz. 3.

76 Ibidem, k. 4. 
W garnizonie funkcjonowała także parafia wojskowa pw. św. Cyryla i św. Metodego ${ }^{77}$, przy cerkwi greckokatolickiej ${ }^{78}$, której proboszczem był ks. Cyprian Chotyniecki ${ }^{79}$. Żołnierze obrządku greckokatolickiego odbywali praktyki religijne w cerkwi pw. Przemienienia Pańskiego, uczestniczyli w niedzielnej Służbie Bożej i w świętach Kościoła greckokatolickiego zgodnie z kalendarzem juliańskim.

Działalność obu parafii wojskowych w okresie dwudziestolecia międzywojennego w Garnizonie Jarosław była istotną częścią struktur wojskowych i służyła nie tylko zaspokajaniu potrzeb duchowych żołnierzy oraz ich rodzin, ale także pogłębianiu patriotyzmu i odpowiedzialności obywatelskiej.

\section{Sztab 24. Dywizji Piechoty przy ul. Jezuickiej}

Na terenie garnizonu stacjonowało dowództwo 24. Dywizji Piechoty (24. DP), które podlegało Okręgowi Korpusu Nr X w Przemyślu. Sztab 24. DP mieścił się początkowo w dawnych obiektach kolegium oo. Jezuitów przy ul. Jezuickiej, a od 4 stycznia 1939 r. został przeniesiony do obiektów dawnego opactwa przy ul. Benedyktyńskiej ${ }^{80}$. Po zakończonej w 1921 r. dyslokacji Wojska Polskiego w Jarosławiu, w skład 24. DP wchodziły: 17. PP w Rzeszowie, 38. PP Strzelców Lwowskich w Przemyślu, 39. PP Strzelców Lwowskich (ul. Kościuszki) i 24. Pułk Artylerii Polowej (od 1931 r. 24. Pułk Artylerii Lekkiej) - przy ul. Poniatowskiego ${ }^{81}$. Dowódcami 24. DP w Jarosławiu byli kolejno: gen. brygady Franciszek Daniel Pawlik, gen. brygady Jan Hempel, gen. brygady Wacław Scaewola-Wieczorkiewicz ${ }^{82}$, gen. brygady Michał Pakosz, płk dypl. Bolesław Krzyżanowski i płk piechoty Bolesław Schwarzenberg-Czerny ${ }^{83}$. Przy 24. DP funkcjonował Wojskowy Klub Sportowy „Ognisko”, od 1934 r. - Wojskowo-Cywilny Klub Sportowy „Ognisko”, a od 1938 r. - Wojskowy Klub Sportowy „Jarosław”.

\section{Koszary w Garnizonie Jarosław Wojska Polskiego}

W latach 1921-1939 żołnierze Garnizonu Jarosław skoszarowani byli w kilku miejscach, których dyslokacja pokojowa obejmowała koszary przy ulicach: Kościuszki, Krakowskiej, Poniatowskiego, Pruchnickiej (ul. Czarnieckiego) oraz 3 Maja.

77 WBH, CAW, sygn. I. 372. 21, Komendy Garnizonów 1918-1939; Kronika Parafialna, „Jarosławskie Wiadomości Parafialne” 1929, nr 2, s. 4; P. Stawecki, Wojsko Marszałka..., s. 220, 222; Służba wojskowa w garnizonach..., s. 78.

78 P. Stawecki, Wojsko Marszałka..., s. 220, 222; J. Odziemkowski, S. Frątczak, Polskie duszpasterstwo wojskowe..., s. 116.

79 Ibidem.

${ }^{80}$ J. Hołub, Dawne Opactwo..., s. 45; J. Stęchły, Zagospodarowanie przestrzenne Wzgórza..., s. 96.

81 G. Bechta, Konferencja - Jarosław..., s. 71-95.

82 T. Skupień, Gen. bryg. Wacław Wieczorkiewicz..., s. 111-112.

83 R. Dalecki, Jarosławski 39 Pułk Piechoty Strzelców Lwowskich $w$ działaniach wojennych 1939 r., „Rocznik Przemyski” 1983, t. XXII-XXIII, Przemyśl 1983, s. 214, 216; Z. Kubrak, 24 Dywizja Piechoty. Zarys organizacji, uzbrojenie i wyszkolenie piechoty dywizyjnej (19211939), „Przemyskie Zapiski Historyczne” 1991-1992, t. 8-9, Przemyśl 1993, s. 121. 


\section{Koszary im. Tadeusza Kościuszki przy ul. Kościuszki}

Dawne koszary Obrony Krajowej Nr 34 zostały w listopadzie 1918 r. przejęte przez Polską Komendę Miasta pod dowództwem mjr. Aleksandra Majewskiego. W koszarach, które otrzymały imię Tadeusza Kościuszki ${ }^{84}$, przeprowadzono mobilizację oraz przysięgę wojskową, którą przyjął na placu apelowym płk Wiktor Jarosz.

39. Pułk Piechoty Strzelców Lwowskich (39. PPSL) ${ }^{85}$ sformowany został w listopadzie 1918 r. we Lwowie i liczył trzy bataliony. Od stycznia 1919 r. stacjonował w Jarosławiu tylko I Batalion Zapasowy ${ }^{86}$ (bataliony II i III stacjonowały w Lubaczowie). W marcu 1921 r. cały sztab 39. PPSL dyslokowany został w tych koszarach. Dnia 4 kwietnia 1919 r. Minister Spraw Wojskowych nadał pułkowi nazwę Strzelców Lwowskich $^{87}$. Według Zygmunta Kubraka, stan osobowy poborowych 39. PPSL w 1937 r. (18 listopada) wynosił 655 żołnierzy, z tego 59\% (389 poborowych) stanowili Polacy, 31\% (203 poborowych) - Ukraińcy, 9,6\% (63 poborowych) - Żydzi ${ }^{88}$. Autor ten stwierdza ponadto, że stosunek procentowy służby żołnierzy poszczególnych narodowości był adekwatny do podobnych garnizonów wojskowych Drugiej Rzeczypospolitej ${ }^{89}$.

Święto pułkowe, połączone z przysięgą młodego rocznika, obchodzono 29 kwietnia ${ }^{90}$. Dowodzili pułkiem kolejno: ppłk piechoty Bolesław Pytel, ppłk piechoty Edward Kańczudzki, ppłk dypl. Zygmunt Trzaska-Durski ${ }^{11}$, ppłk dypl. Józef Gruszka oraz ppłk dypl. Roman Szymański ${ }^{92}$. Przy 39. PPSL działał amatorski zespół teatralny, kasyno dla podoficerów zawodowych, Spółdzielnia Spożywcza im. Tadeusza Kościuszki, orkiestra dęta pod batutą kapelmistrzów: por. Tadeusza Dziadowicza i por. Wiktora Soczewicza oraz Wojskowe Koło Sportowe, które zawiązane zostało 22 września 1923 r. ${ }^{93}$ Znaczące sukcesy odnosili żołnierze 39. PPSL w zawodach strzeleckich o mistrzostwo Okręgu Korpusu. Do wyróżniających się sportowców w grupie podoficerów należeli st. sierż. Roman Benedykt oraz sierż. Stanisław Kulas, natomiast wśród oficerów - dowódca pułku, płk dypl. Zygmunt Trzaska-Durski ${ }^{94}$.

W 1928 r., w 10. rocznicę utworzenia 39. PPSL, wręczono honorowe odznaki pułkowe zaproszonym gościom: bp. Władysławowi Bandurskiemu, płk. Gustawowi

84 M. Orłowicz, Jarosław, jego przeszłość..., s. 117.

85 Cyfrę 39 pułk otrzymał na pamiątkę numeru chorągwi Spytka z Jarosławia, która brała udział w bitwie pod Grunwaldem w $1410 \mathrm{r}$.

86 S. Adamik, Kronika Szpitala psychiatrycznego w Jarosławiu. 60 lat działalności, Jarosław 2014, s. 24-25; Z. Kubrak, Zarys historii wojennej pułków polskich w kampanii wrześniowej. 39 pułk piechoty, Pruszków 1999, s. 8; idem, 24 Dywizja Piechoty..., s. 120.

87 W. Sobocki, Jednostki Garnizonu..., s. 161.

88 Z. Kubrak, 24 Dywizja Piechoty..., s. 127; idem, Zarys historii wojennej..., s. 12.

89 Idem, 24 Dywizja Piechoty..., s. 127.

90 Uroczystość 10-lecia 39 pp. Strzelców Lwowskich, „Express Jarosławski” 1929, nr 18, s. 2; Zaprzysiężenie rekruta w Rynku, „Express Jarosławski” 1929, nr 18, s. 2-3; mjr W. Pączek, Przemówienie wygłoszone do żołnierzy 39 pp. z okazji święta pułku w dniu 29 IV br., „Gazeta Jarosławska" 1930, nr 18, s. 3.

91 Kronika. Zaszczytny awans, „Tygodnik Jarosławski” 1935, nr 2, s. 1-2; 39 pp. Strzelców Lwowskich w karykaturze Jotesa, b.m., b.r. [zbiory prywatne Jerzego Czechowicza].

92 R. Dalecki, Jarosławski 39 Pułk Piechoty..., s. 214; Z. Kubrak, Zarys historii wojennej..., s. 10; W. Sobocki, Jednostki Garnizonu..., s. 163-164; T. Skupień, Gen. bryg. Wacław Wieczorkiewicz..., s. 127.

93 DALO, F. 1, op. 54, spr. 4089, Wojskowe Koło Sportowe 39 pp., 1923-1932, passim.

94 Z. Kubrak, 24 Dywizja Piechoty..., s. 127. 
Paszkiewiczowi, komisarzowi Otto Nadolskiemu i Stanisławowi Sierankiewiczowi burmistrzowi Jarosławia ${ }^{95}$. W 1934 r., w 15. rocznicę obchodów odzyskania niepodległości i 20. rocznicę wyjścia z Ziemi Jarosławskiej Legionów, odsłonięto na terenie koszar Pomnik Niepodległości z napisem na tablicy okolicznościowej:

Whołdzie wielkiemu wodzowi twórcy Armii Polskiej I-szemu Marszałkowi Józefowi Piłsudskiemu dla uczczenia oficerów i żołnierzy 39 pp. Strzelców Lwowskich poległych w walkach o wytyczenie granic Oddanej Ojczyzny dnia 29 kwietnia 1934 r. jako w 15-letniq rocznicę zwycięskich bojów pułku o Lwów pomnik ten przez społeczeństwo powiatów jarosławskiego, lubaczowskiego i przeworskiego wzniesiony został ${ }^{96}$.

Kompleks koszarowy przy ul. Kościuszki tworzyło kilka dwupiętrowych budynków dla wojska, magazyny, stajnie dla koni oraz administracyjny budynek sztabu. W latach 1937-1939 na terenie koszar funkcjonował szpital wojskowy, którego komendantem był dr Eligiusz Sobocki, jego zastępcą mjr M. Ormowski, natomiast lekarzem mjr dr Klocek ${ }^{97}$. W Wojskowej Izbie Przyjęć pracowali lekarze: kpt. dr Józef Sławik, por. dr I. Gryziewicz oraz stomatolog dr Adam Zys. Przy pułku działała Powiatowa Komenda Uzupełnień, skupiając się na uzupełnianiu pododdziałów 24. DP i 39. PPSL ${ }^{98}$.

W ramach ogłoszonej mobilizacji Wojska Polskiego do obrony kraju, pułk opuścił Jarosław w pierwszych dniach września 1939 roku ${ }^{99}$.

\section{Koszary Piechoty przy ul. Krakowskiej (od 1920 r. dra Adolfa Dietziusa)}

W koszarach tych od 1922 r. stacjonował 3. Pułk Piechoty Legionów (3. PPL) ${ }^{100}$. Pułk wchodził w skład 2. Dywizji Piechoty stacjonującej w Kielcach. Dowódcami 3. PPL w latach 1922-1939 byli kolejno: mjr Tadeusz Danilewicz, mjr Józef Szczepan, kpt. Kazimierz Brożek, płk Michał Zabdyr, płk Leon Grot, płk Mieczysław Łukasik i płk Zygmunt Berek.

Święto pułku, połączone z przysięgą młodego rocznika, obchodzono 30 września101. W 1928 r. dowództwo zorganizowało z tej okazji „Tydzień Sportu”. Żołnierze rywalizowali w drużynowym biegu patrolowym, zawodach strzeleckich na strzelnicy garnizonowej Szczytna oraz strzelnicy małokalibrowej na terenie koszar. Uroczystość zakończył wspólny obiad oraz zabawa taneczna dla żołnierzy i osób cywilnych

95 W.J. Wysocki, A.Cz. Żak., Biskup Władysław Bandurski, Pruszków 1997, s. 95.

96 Pomnik ten, zniszczony przez Niemców w 1939 r., został przywrócony w 2001 r. z dodatkową tablicą: [...] W 83 rocznicę Odzyskania Niepodległości tablicę zniszczoną przez okupanta w 1939 r. przywraca Stowarzyszenie Miłośników Jarosławia, SP ZOZ, społeczeństwo miasta oraz Radni Miasta i Powiatu Jarosławskiego. Jarosław 11 XI 2001 r.

97 S. Sobocki, Szpitale II Rzeczypospolitej. Szpital Wojskowy w Jarosławiu, „Rocznik Stowarzyszenia Miłośników Jarosławia", t. XIX, Jarosław 2011-2012, s. 152-162; 39 pp. Strzelców Lwowskich w karykaturze...

98 W. Rogala, Monografia Wojskowej Komendy Uzupełnień 1944-2014, Jarosław 2014, s. 16.

99 Obecnie na terenie dawnych koszar znajduje się Specjalistyczny Psychiatryczny Zespół Opieki Zdrowotnej im. prof. Antoniego Kępińskiego.

${ }^{100}$ Pułk został sformowany 15 VIII 1914 r. w Mszanie, wchodząc w skład 2. Brygady Legionów Polskich, gdzie dowódcą I batalionu był gen. Józef Haller.

${ }^{101}$ Uroczystości 15-lecia 3 pp. L[egionów] połączone ze świętem pułku, „Express Jarosławski” 1929, nr 40, s. 1; Święto pułku, „Express Jarosławski” 1937, nr 26, s. 3. 
w sali kasyna pułku102. W 1929 r., dla uczczenia 15. rocznicy powstania pułku, poświęcono Krzyż Karpacki (kopia siedmiometrowego krzyża, wzniesionego w 1914 r. przez legionistów na Przełęczy Legionów w Karpatach Wschodnich 1110 m n.p.m.) i wmontowano go w koszarach.

Na terenie koszar od ul. Krakowskiej funkcjonował do 1937 r. szpital wojskowy, którego komendantem był ppłk dr Bronisław Pawlikowski, natomiast lekarzami Grzegorz Turzański oraz kpt. dr Józef Sławik ${ }^{103}$. W szpitalu dostępna była kaplica, w której katolicki kapelan sprawował Mszę świętą dla chorych żołnierzy ${ }^{104}$.

Przy pułku działał Wojskowy Klub Sportowy „Trzeciak”105 oraz orkiestra dęta pod batutą kapelmistrza kpt. Bolesława Walek-Walewskiego. W 1932 r. orkiestra wyjechała na kilka miesięcy do Truskawca-Zdroju, „[...] by umilać czas kuracjuszom oraz do Poznania, gdzie dawała koncerty podczas Wystawy Krajowej"106. Wyróżniającym się muzykiem był jarosławianin, kpr. Michał Zieliński ${ }^{107}$, który podczas pobytu w Truskawcu skomponował słynną piosenkę Serce w plecaku ${ }^{108}$.

Oficerowie i żołnierze z 3. PPL mieli możliwość korzystania z biblioteki ogólnej i biblioteki podoficerskiej oraz czytelni prasy. Należeli do Funduszu Pożyczkowego Podoficeró $\mathrm{w}^{109}$, uczestniczyli w kursach przysposobienia wojskowego, działali w amatorskim zespole teatralnym, prowadzili herbaciarnię oraz spółdzielnię spożywczą. Bardzo uroczyście obchodzono Dzień Spółdzielczości, zapraszając na uroczystości korpus oficerski i żołnierzy pozostałych pułków garnizonu, w których funkcjonowały spółdzielnie.

Doniosłym wydarzeniem były obchody 20 . rocznicy utworzenia pułku. Uroczystości jubileuszowe odbyły się 29 i 30 września 1934 r. ${ }^{110}$

W 1935 r. zmarł w koszarach szer. Abraham Silberstein. Żołnierz ten cieszył się sympatią przełożonych i kolegów, czego dowodem był uroczysty pogrzeb z udziałem

${ }_{102}$ Święto pułkowe, „Głos Jarosławski” 1928, nr 38, s. 2.

${ }^{103}$ M. Demkowicz-Dobrzański, Legenda czy prawda o grobie hetmana Karola Chodkiewicza w Jarosławiu $w$ świetle historycznych badań, Jarosław 1937, s. 21; Z. Zięba, Jarosławskie cmentarze, Jarosław 2008, s. 454.

${ }^{104}$ AAPwP, Teczka Jarosław, TPS/88/2, 10 VIII $1923 \mathrm{r}$.

${ }^{105}$ Kronika sportowa: Polonia: Trzeciak (K.S. 3 pp. leg.), „Ziemia Przemyska” 1927, nr 41, s. 4.

${ }^{106}$ Wyjazd orkiestry 3 pp. leg. na sezon do Truskawca, „Express Jarosławski” 1932, nr 19, s. 3; Wyróżnienie 3 pp Legionów, „Express Jarosławski” 1929, nr 15, s. 3; Uznanie prasy poznańskiej dla kapelmistrza orkiestry 3 pp porucznika Kuczery, „Express Jarosławski” 1929, nr 33, s. 2.

${ }^{107}$ Michał Zieliński - ur. 15 IX 1905 r. w Jarosławiu. Żołnierz Wojska Polskiego, kapral 3. Pułku Piechoty Legionów, członek orkiestry dętej tegoż pułku. Utalentowany poeta i kompozytor, autor piosenki (słowa i muzyka) Serce w plecaku. Zmarł 14 XI 1972 r., pochowany na Starym Cmentarzu w Jarosławiu. Upamiętniony w 1972 r. na tablicy wmurowanej w ścianę budynku dawnego Kasyna Wojskowego przy ul. Grunwaldzkiej 11 oraz w 2013 r. na tablicy z popiersiem w Centrum Kultury i Promocji w Jarosławiu, Rynek 5. Corocznie odbywa się w Jarosławiu Ogólnopolski Festiwal Piosenki Ojczystej Serce w Plecaku im. Michała Zielińskiego.

${ }^{108}$ W.J. Podgórski, Dlaczego Michał Zieliński nie podbił Warszawy, „Rocznik Stowarzyszenia Miłośników Jarosławia”, t. XX, 2013-2014, Jarosław 2014, s. 389-410; M. Zieliński, Serce w plecaku... bije nadal, Jarosław 2013, passim.

${ }^{109}$ Statut Funduszu Pożyczkowego Podoficerów 39 P.P. Strzelców Lwowskich, zatwierdzony przez dowódcę pułku ppłk. dypl. Zygmunta Trzaska-Durskiego 1 IV 1933 r. [zbiory prywatne Jerzego Czechowicza].

${ }^{110}$ Dwudziestolecie 3 pp. Leg., „Tygodnik Jarosławski” 1934, nr 38, s. 3; Program uroczystości 20-lecia 3 pp. Legionów, „Tygodnik Jarosławski” 1934, nr 39, s. 1-2. 
orkiestry wojskowej, kombatantów żydowskich oraz mieszkańców Jarosławia. Egzekwie zostały odprawione przez głównego kantora przed Dużą Synagogą ${ }^{111}$. Egzemplifikacja podobnego wydarzenia dotyczyła kpr. rezerwy Ozjasza Storcha, który zginął w 1938 r. podczas manewrów żołnierzy rezerwy 3. PPL na Zaolziu. Symboliczny ceremoniał nabożeństwa żałobnego odbył się na terenie macierzystych koszar, przy licznym udziale żołnierzy Garnizonu Jarosław i osób cywilnych ${ }^{112}$.

\section{Koszary Artylerii im. Księcia Józefa Poniatowskiego przy ul. Poniatowskiego}

W koszarach stacjonował 24. Pułk Artylerii Polowej (24. PAP) ${ }^{113}$. Sformowany 9 października 1921 r. pułk wchodził w skład 24. Dywizji Piechoty ${ }^{114}$. W 1931 r. został przemianowany na Pułk Artylerii Lekkiej (PAL), a w 1938 r. nadano mu imię Króla Jana III Sobieskiego ${ }^{115}$. Na terenie koszar od 1934 r. funkcjonowała Fabryka Sucharów produkująca suchary z mąki pszennej, zaopatrując w Polsce wszystkie garnizony Wojska Polskiego ${ }^{116}$. Święto pułku obchodzono 4 maja ${ }^{117}$. Dowódcami 24. PAP oraz 24. PAL w latach 1921-1939 byli kolejno: ppłk art. Wiktor Poray-Kuczewski, ppłk art. inż. Jan Lange, ppłk art. Aleksander Batory, ppłk art. Eugeniusz Dąbrowski, płk art. Edward d’Erceville, ppłk dypl. art. Stefan Brzeszczyński, ppłk art. Władysław Kaliszek, ppłk art. Tadeusz Michałowski.

\section{Koszary Kawalerii przy ul. Piekarskiej}

Dawne koszary c.k. kawalerii pełniły w okresie międzywojennym rolę magazynów oraz zaplecza technicznego dla garnizonowej konnicy. Wśród kilku obiektów militarnych i funkcjonującej na terenie koszar piekarni wojskowej ważne zadania miały dwie kryte ujeżdżalnie: Nr 1 - do nauki jazdy konnej i Nr 2, w której zlokalizowano Halę Sportową, przeznaczoną do rozgrywania zawodów konnych i spotkań żołnierzy garnizonu $^{118}$. Na przykład, członkowie Klubu Jeździeckiego Małopolski Środkowej, działający przy Wojskowym Klubie „Ognisko”, urządzili tam w 1935 r. zawody hippiczne dla wojskowych i cywilów ${ }^{119}$.

${ }^{111}$ Z kroniki żałobnej, „Express Jarosławski” 1935, nr 24, s. 6.

112 Żałobne nabożeństwo za błp. kaprala Storcha, „Chwila” 1938, nr 1316, s. 7; Zmarły bohater..., „Chwila” 1938, nr 1316, s. 10; Kronika, „Tygodnik Jarosławski” 1938, nr 13, s. 7.

${ }^{113}$ WBH, CAW, sygn. I. 322.24. 24 Pułk Artylerii Lekkiej (PAL) im. Króla Jana III Sobieskiego, teczka: 1-17, 18.

${ }^{114}$ Rozformowanie pułku nastąpiło 20 IX 1939 r. Patrz: E. Płocica, 24 Pułk Artylerii Polowej w Jarosławiu, „Rocznik Stowarzyszenia Miłośników Jarosławia”, t. XIII, 1994-1999, Jarosław 2000, s. 103-111.

115 D. Słota, Garnizon Jarosław 1934-1939, [w:] Służba wojskowa w garnizonach..., s. 55.

${ }^{116}$ Archiwum Fabryki Ciastek Mondalez w Jarosławiu [dalej: AFCMwJ], Kronika Zakładów Pieczywa Cukierniczego San, br. sygn., k. 1-3.

${ }^{117}$ Parafia wojskowa, „Jarosławskie Wiadomości Parafialne” 1929, nr 1, s. 4; Uroczystości Święta pułkowego 24 pap, „Express Jarosławski” 1929, nr 18, s. 2; Święto Pułkowe 24 PAP, „Express Jarosławski” 1929, nr 19, s. 2; E. Płocica, 24 Pułk Artylerii Polowej..., s. 105.

118 Obecnie na terenie dawnych koszar znajduje się Galeria Handlowa „Stara Ujeżdżalnia”.

${ }^{119}$ Wielkie zimowe zawody konne, „Gazeta Jarosławska” 1935, nr 3, s. 6. 


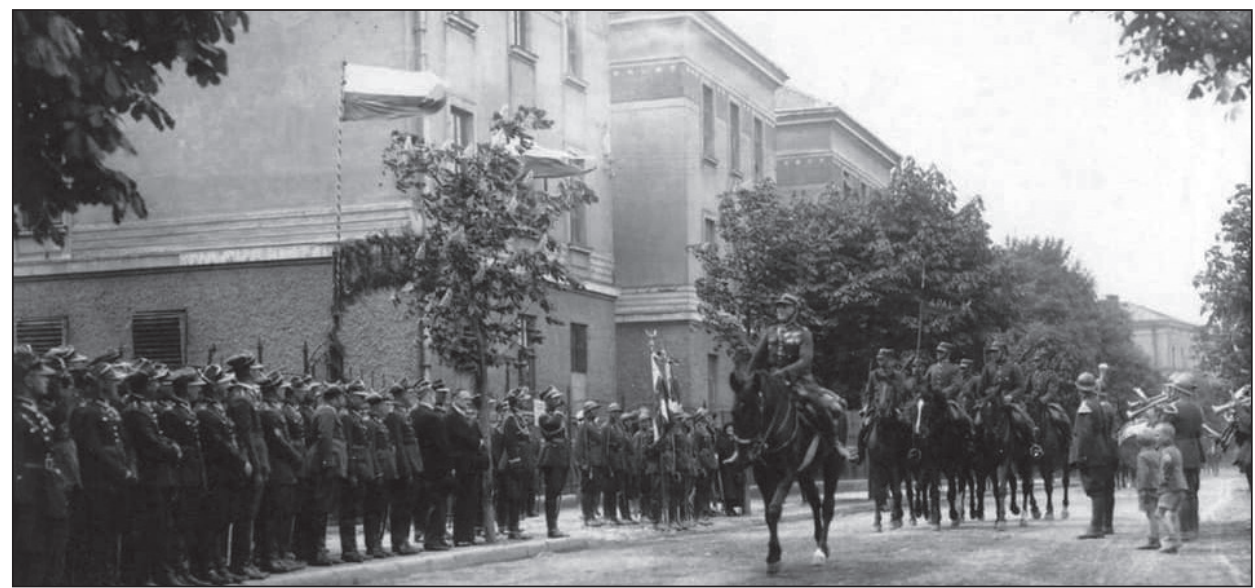

Fot. 3. Jarosław. Defilada oddziału kawalerii na ul. Księcia Józefa Poniatowskiego (źródło: Muzeum w Jarosławiu Kamienica Orsettich).

\section{Koszary przy ul. Czarnieckiego ${ }^{120}$}

W latach 1921-1930 stacjonował w dawnych c.k. koszarach 2. Pułk Łączności. Po przeprowadzonej w 1930 r. reorganizacji wojsk łączności pułk przemianowany został na 6. Batalion Telegraficzny. W koszarach stacjonowały Jednostka taborów oraz Kompania łączności 24. DP. Dowódcami jednostki byli kolejno: mjr łączności Augustyn Stręk, mjr łącz. Zenon Nosowicz, ppłk łącz. Stefan Popiel, płk Artur Ombach. Święto pułkowe połączone z przysięgą młodego rocznika obchodzono 29 czerwca. Przy pułku działała Spółdzielnia spożywcza i drużyna piłki nożnej ${ }^{121}$.

\section{Koszary Artylerii im. Jana Henryka Dąbrowskiego przy ul. 3 Maja}

W koszarach im. gen. Jana Henryka Dąbrowskiego ${ }^{122}$ stacjonowały: 10. Dywizjon Artylerii Konnej (10. DAK) ${ }^{123}$, wchodzący w skład 10. Pułku Artylerii Ciężkiej w Przemyślu ${ }^{124}$, Kompania 24. Dywizji Piechoty oraz 10. Zapas Młodych Koni. Na terenie koszar znajdowała się Szkoła Podchorążych Rezerwy Piechoty 24. DP ${ }^{125}$. Dowódcami 10. DAK byli: ppłk art. Witold Poray-Kuczewski, ppłk art. Henryk Kreiss, ppłk art.

${ }^{120}$ Obecnie na terenie dawnych koszar funkcjonuje Państwowa Wyższa Szkoła Techniczno-Ekonomiczna im. Ks. Bronisława Markiewicza.

${ }^{121}$ Kronika sportowa: 2 p[ułk] wojsk łączności (Jarosław) - 4 pp. leg. (Kielce), „Ziemia Przemyska” 1922, nr 42, s. 4; 2 p [ułk] Łączności Jarosław, „Ziemia Przemyska” 1923, nr 5, s. 4; 2 pułk Łq̨czności Jarosław : Polonia II 6:0, „Ziemia Przemyska” 1923, nr 5, s. 4; Kronika przemyska: Polonia I (Przemyśl) - 2 p [ułk] łącz[ności] (Jarosław), „Ziemia Przemyska” 1926, nr 23, s. 4.

${ }^{122}$ ANwK, sygn. 29/1408/0/-/844, Projekt instalacji wodno-kanalizacyjnej w koszarach im. gen. Dąbrowskiego w Jarosławiu-Głęboka, passim.

${ }^{123}$ S. Sobocki, Szpitale II Rzeczypospolitej..., s. 152-162.

${ }^{124}$ M. Orłowicz, Jarosław, jego przeszłość..., s. 112.

${ }^{125}$ APP, AmJ, sygn. 681, Ogłoszenie z dnia 9 kwietnia 1930 r. burmistrza miasta Jarosławia w sprawie zgłoszenia się żołnierzy rezerwy absolwentów szkoły celem uzyskania certyfikatu jej ukończenia. 


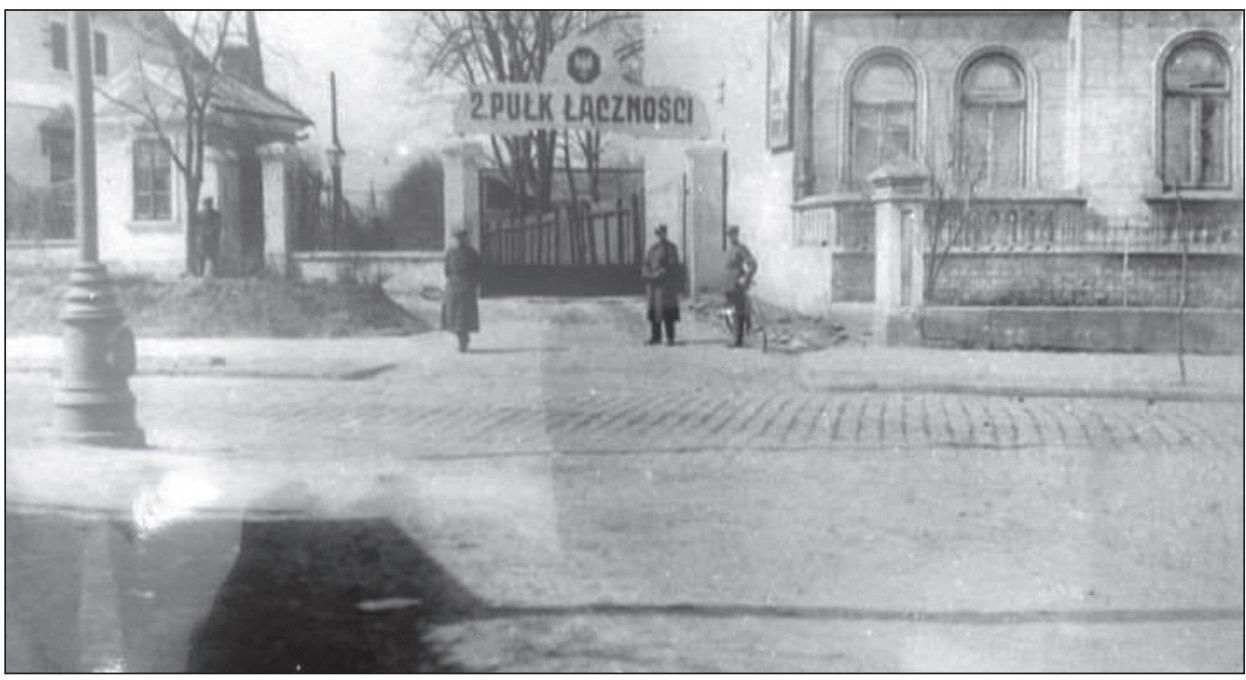

Fot. 4. Jarosław. Brama wjazdowa do 2. Pułku Łączności (źródło: Muzeum w Jarosławiu Kamienica Orsettich).

August Trzos, ppłk dypl. art. Tadeusz Leon Sheybal oraz ppłk art. Jan Woźniakowski. Święto 10. DAK obchodzono początkowo 29 czerwca $^{126}$, a od 1928 r. - 15 sierpnia $^{127}$.

\section{Batalion Obrony Narodowej Jarosław}

W 1937 r. w Jarosławiu sformowany został Batalion Obrony Narodowej Jarosław, podległy Podkarpackiej Brygadzie Obrony Narodowej i dowódcy Okręgu Korpusu Nr X w Przemyślu. Dowódcą batalionu w latach 1937-1939 był kpt. Władysław Bochenek. Batalion ON Jarosław uczestniczył w kampanii wrześniowej w 1939 r. w składzie 3. Brygady Górskiej ${ }^{128}$.

\section{Oddział Budownictwa Wojskowego}

Od 1920 r. w garnizonie utworzony został Oddział Budownictwa Wojskowego, dowodzony przez inż. Zygmunta Krzysika. Oddział BW wybudował m.in. Dom Żołnierza przy ul. Słowackiego i prowadził prace remontowe we współpracy z kpt. inż. Mieczysławem Demkowicz-Dobrzańskim ${ }^{129}$ w obiektach dawnego Opactwa Panien Benedyktynek ${ }^{130}$.

126 Święto pułku, „Tygodnik Jarosławski” 1928, nr 25, s. 2.

${ }^{127}$ Parafia wojskowa, „Jarosławskie Wiadomości Parafialne” 1929, nr 1, s. 4.

${ }^{128}$ W. Rogala, Monografia Wojskowej Komendy..., s. 22.

${ }^{129}$ Mieczysław Demkowicz-Dobrzański, herbu Sas - ur. 26 I 1882 r. Major Wojska Polskiego. Członek Zarządu Towarzystwa Miłośników Starego Jarosławia. Projektant remontowanych baszt dawnego Opactwa Panien Benedyktynek. Członek Okręgowej Komisji Konserwatorskiej Województwa Lwowskiego. Autor publikacji Legenda czy prawda o grobie hetmana Karola Chodkiewicza w Jarosławiu w świetle historycznych badań (Jarosław 1937). Zmarł 11 I 1942 r. w niemieckim obozie zagłady KL Auschwitz.

${ }^{130}$ M. Orłowicz, Jarosław, jego przeszłość..., s. 108; J. Stęchły, Zagospodarowanie przestrzenne Wzgórza..., s. 95. 


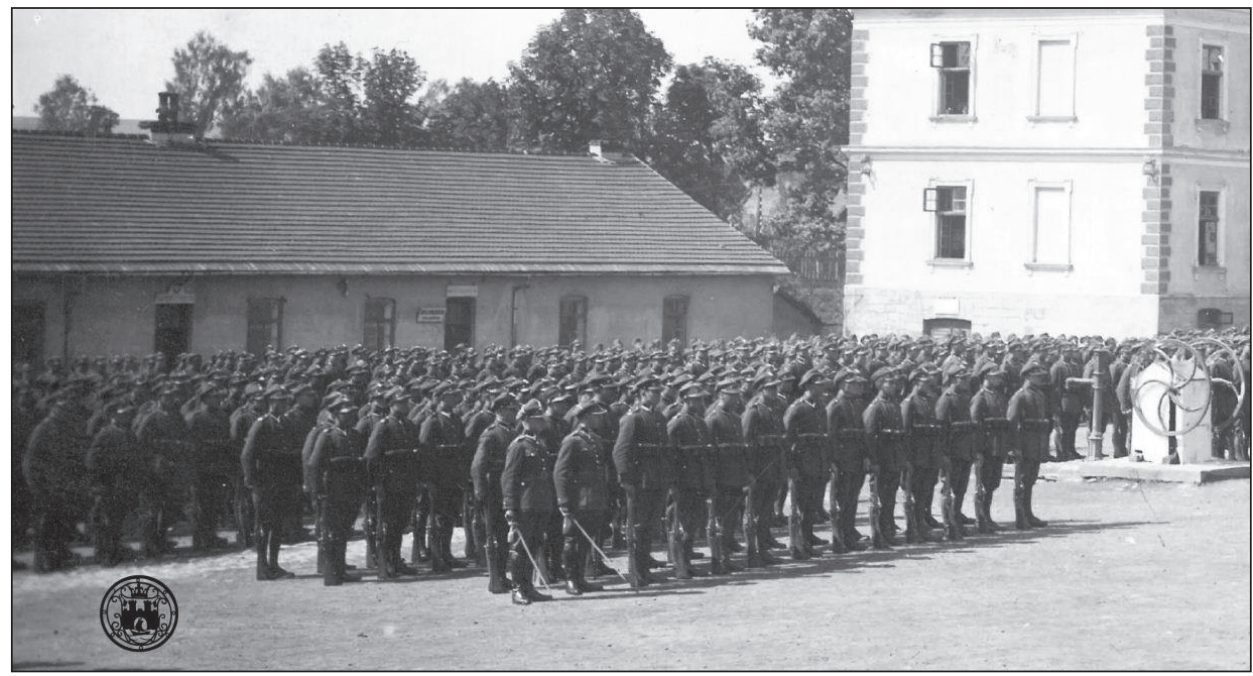

Fot. 5. Jarosław. Plac alarmowy w 2. Pułku Łączności (źródło: Muzeum w Jarosławiu Kamienica Orsettich).

\section{Powiatowa Komenda Uzupełnień}

W listopadzie 1918 r. powstała w Jarosławiu Powiatowa Komenda Uzupełnień, która rozpoczęła zaciągi mężczyzn urodzonych w latach 1883-1901 w powiatach: Jarosław, Przeworsk i Łańcut. W styczniu 1919 r. PKU w Jarosławiu przeniesiona została do PKU w Przemyślu, otrzymując nazwę III Komisji Przeglądowej. Po wprowadzeniu ustawy O powszechnym obowiq̨zku służby wojskowej działała w Jarosławiu od 23 maja 1924 r. Powiatowa Komenda Uzupełnień dla powiatów Jarosław i Lubaczów, która podległa Dowództwu Okręgu Korpusu Nr V w Krakowie. Od stycznia 1939 r. zmieniono jej nazwę na Komendę Rejonów Uzupełnieńn ${ }^{131}$.

\section{Dom Żołnierza Polskiego im. Marszałka Józefa Piłsudskiego przy ul. Słowackiego}

Działalność kulturalno-oświatową dla żołnierzy i ludności cywilnej prowadzili w garnizonie, w Domu Żołnierza Polskiego, członkowie Towarzystwa Domu Żołnierza Polskiego ${ }^{132}$. Otwarcie placówki nastąpiło 19 marca 1933 r., a poświęcenia dokonał 26 września 1933 r. ks. ppłk Walenty Pączek - proboszcz parafii wojskowej ${ }^{133}$. W 1935 r. obiektowi nadano imię Marszałka Polski Józefa Piłsudskiego. Z tej okazji ufundowano tablicę okolicznościową z napisem:

Dom Żołnierza w Jarosławiu wybudowano z ofiar wojska i społeczeństwa powiatu jarosławskiego, przeworskiego i lubaczowskiego na chwałę twórcy Armii Polskiej, a żołnierzowi na pożytek.

Pierwszym prezesem Zarządu Towarzystwa Domu Żołnierza Polskiego został gen. brygady Wacław Scaewola-Wieczorkiewicz ${ }^{134}$. W sali widowiskowej organizowa-

\footnotetext{
${ }^{131}$ W. Rogala, Monografia Wojskowej Komendy..., s. 16-17; Z. Kubrak, 24 Dywizja Piechoty..., s. 126. 132 DALO, F. 1, op. 54, spr. 4123, Stowarzyszenie Dom Żołnierza, 1930-1937, Statut, par. 3, k. 3.

133 Poświęcenie Domu Żołnierza Polskiego, „Express Jarosławski” 1933, nr 3, s. 3.

${ }^{134}$ Zarząd Towarzystwa Budowy Domu Żołnierza reprezentowali: ppłk dypl. Zygmunt Trza-
} 
no uroczystości narodowe, rocznicowe i kulturalne, w których brali udział mieszkańcy Jarosławia. W obiekcie funkcjonowała biblioteka z czytelnią, świetlica, bilard oraz kino „Dom Żołnierza”135. Funkcjonowało też Towarzystwo Wiedzy Wojskowej Garnizonu Jarosław, którego członkowie organizowali dla mieszkańców miasta odczyty o tematyce związanej z działalnością żołnierzy w społeczeństwie. Dodatkowo w obiekcie działała Sekcja Teatralno-Muzyczna „Ognisko” Podoficerów Zawodowych Garnizonu Jarosław ${ }^{136}$ oraz Zespół Teatralny 39. Pułku Piechoty Strzelców Lwowskich ${ }^{137}$.

\section{Kasyno Garnizonowe i Kasyna Pułkowe}

Do dyspozycji wszystkich oficerów garnizonu pozostawał budynek Kasyna Garnizonowego, natomiast dla podoficerów dostępne były Kasyna Pułkowe przy ulicach: Poniatowskiego, Kościuszki, Krakowskiej, Słowackiego i 3 Maja ${ }^{138}$. Kasyna gromadziły kadrę oficerską i podoficerską w czasie wolnym od czynności zawodowych. W pomieszczeniach restauracyjnych, czytelniach, bibliotekach oraz salach reprezentacyjnych prowadzono działalność patriotyczną i kulturalną. Obiekty te stanowiły w okresie międzywojennym centrum życia kulturalnego elity jarosławskiego garnizonu.

\section{Związki mundurowe}

Żołnierze zawodowi Garnizonu Jarosław należeli do Oddziału Związku Podoficerów Zawodowych, natomiast podoficerowie i oficerowie rezerwy - do trzech kół. Pierwsze z nich to Koło Związku Oficerów Rezerwy Rzeczypospolitej (KZORR), któremu przewodniczyli kolejno: mjr rezerwy Franciszek Hornung, kpt. Serafin Demkowicz-Dobrzański ${ }^{139}$ i Oskar Friser ${ }^{140}$. Drugim było Koło Związku Podoficerów Rezerwy Wojska Polskiego Federacji Polskich Związków Obrony Ojczyzny (ZPRWPFPZO0), którego przewodniczącym był Teodor Duda, natomiast sekretarzem - Adam Duda. Trzecie to Koło Związku Podoficerów Rezerwy (KZPR) z przewodniczącym zarzą-

ska-Durski, kpt. Kazimierz Filip, chor. Hubert, kpt. Stanisław Kopeć, adwokat dr Marian Lisowiecki, st. sierż. Malec, ks. Zygmunt Męski, por. Michał Moskowityn, Edmund Prezentkiewicz, Stanisław Sierankiewicz, mjr Henryk Smotrecki. Komisję Rewizyjną tworzyli: Stanisław Kastner, mjr Józef Królikiewicz, st. ogniomistrz Nowakowski. Patrz: $Z$ okazji otwarcia „Domu Żołnierza”, „Gazeta Jarosławska” 1933, nr 6, s. 2.

135 Ibidem.

${ }^{136}$ Z teatru, „Express Jarosławski” 1930, nr 34, s. 3.

${ }_{137}$ Zespół amatorski 39 pp. Strzelców Lwowskich, „Tygodnik Jarosławski” 1935, nr 2, s. 2.

${ }^{138}$ W. Kielar, I nasze młode lata, Wrocław 1987, s. 265.

${ }^{139}$ Członkami Zarządu KZORR byli: Tadeusz Zieliński, Władysław Duchniewicz, Feliks Kogut, L. Farbowski, S. Kaczmarski, J. Trzaskowski. Komisję Rewizyjną tworzyli Stanisław Piotrowski i Józef Sobień. Po Walnym Zebraniu i wyborach członkami Zarządu KZORR zostali: dr Zdzisław Karpiński, J. Łabudzki, W. Tumidajski, Bolesław Tylko, W. Lorenz. Do Komisji Rewizyjnej wybrani zostali: Tadeusz Zieliński, Henryk Haut, J. Król, F. Raczyński i J. Grąz. Patrz: Związek Oficerów Rezerwy RP Koło w Jarosławiu, „Głos Jarosławski” 1928, nr 17, s. 3; Zwiq̨zek Oficerów Rezerwy, „Wiadomości Jarosławskie” 1928, nr 11, s. 4.

${ }^{140}$ Członkami Zarządu KZORR byli: Tadeusz Zieliński, Władysław Duchniewicz, Feliks Kogut, L. Farbowski, Stanisław Kopystyński, S. Kaczmarski, Stanisław Piotrowski. Patrz: Ze Zwiq̨zku Oficerów Rezerwy, „Express Jarosławski” 1929, nr 11, s. 2. 
Jacek Marian Hołub

du Józefem Krausem ${ }^{141}$. Dodatkowo żołnierze rezerwy należeli do Oddziału Związku Ochotników Armii Polskiej oraz do Oddziału Federacji Polskich Związków Obrony Ojczyzny (FPZO0). Federację reprezentował prezes Tadeusz Zieliński ${ }^{142}$.

\section{Uniwersytet Żołnierski}

Rozkazem Sztabu Generalnego Wojska Polskiego z dnia 14 lutego 1919 r. w Garnizonie Jarosław powołany został Uniwersytet Żołnierski (UŻ), którego zadaniem statutowym było prowadzenie działalności edukacyjnej i kulturalnej wśród żołnierzy ${ }^{143}$. Służby oświatowe pułków prowadziły działania zmierzające do zmniejszenia stopnia analfabetyzmu w społeczeństwie. Tworzono w tym celu żołnierskie szkoły początkowe, w których uczono czytania, pisania i liczenia ${ }^{144}$. Żołnierze mieli również możliwość korzystania z biblioteki UŻ oraz czytelni prasy. Członkami Zarządu UŻ byli: por. Witold Andruszewicz, Mieczysław Orłowicz, płk Wiktor Jarosz, ppor. Adam Danecki, ppor. Witold Bobiński oraz plut. Zygmunt Orłowicz ${ }^{145}$.

\section{Skład osobowy Garnizonu}

Po odzyskaniu przez Polskę niepodległości skład osobowy Garnizonu Jarosław był niejednolity pod względem narodowościowym. Liczby żołnierzy stacjonujących w garnizonie nie można ustalić precyzyjnie, gdyż stan osobowy był zmienny. Na podstawie słabo zachowanej, w dużym stopniu zdekompletowanej bazy źródłowej, liczba ta oscylowała między 3500-4000 żołnierzy i oficerów ${ }^{146}$. Natomiast w świetle danych pierwszego powszechnego spisu ludności z 1921 r., Jarosław zamieszkiwały 19973 osoby (bez wojska) ${ }^{147}$, a podczas drugiego spisu - w 1931 r. - mieszkało tam 22195 osób (bez wojska) ${ }^{148}$. W jednostkach Garnizonu służyli: Polacy, Ukraińcy (Rusini), Żydzi

${ }^{141}$ Członkami Zarządu KZPR byli: Franciszek Maciejowski, Jan Szlachetka, Stanisław Kogut, Józef Kopeć, Adam Migas. Patrz: Na Walnym Zebraniu, „Gazeta Jarosławska” 1938, nr 10, s. 3.

${ }^{142}$ Członkami Zarządu Oddziału FPZOO w 1928 r. byli: Leopold Leichtfierd, Teodor Duda, Stanisław Gabriel, Bolesław Tylko, Jan Łabudzki i Władysław Pasek. Patrz: Zebranie organizacyjne Federacji Pol[skich] Zw[iq̨zków] Obrony Ojczyzny, „Wiadomości Jarosławskie” 1928, nr 37, s. 4.

${ }^{143}$ Troska o poziom oświaty, „Głos Jarosławski” 1929, nr 28, s. 3.

${ }^{144}$ Ustawa z dnia 21 lipca 1919 r. O przymusowym nauczaniu w Wojsku Polskim, (Dz. Pr. PP z 1919 r., Nr 63, poz. 373). Na przykład, w 24. Dywizji Piechoty w Jarosławiu przymusowe nauczanie w okresie jesienno-zimowym prowadzono codziennie po południu, $w$ tym dwie lekcje po 45 minut w dzień powszedni, jedną lekcję w niedziele i święta. Patrz: J. Odziemkowski, Armia i społeczeństwo II Rzeczypospolitej, Warszawa 1996, s. 43.

${ }^{145}$ W. Bobiński, Przedmowa, [w:] Jarosław, jego przeszłość.., s. 5-9.

${ }^{146}$ MwJKO, sygn. 52, Zbiór materiałów do dziejów miasta Jarosławia w latach 1920-1939, k. 3, 59; P. Stawecki, Wojsko Marszałka..., s. 150; 100 rocznica wybuchu..., s. 135.

${ }^{147}$ Skorowidz miejscowości Rzeczypospolitej Polskiej opracowany na podstawie wyników pierwszego powszechnego spisu ludności z dn. 30 września 1921 r. i innych źródeł urzędowych, t. XIII: Województwo Lwowskie, Warszawa 1924, s. 13, 66.

${ }^{148}$ Drugi powszechny spis ludności z dnia 9 grudnia 1931 roku. Mieszkania i gospodarstwa domowe. Ludność. Stosunki zawodowe: Województwo Lwowskie bez miasta Lwowa, seria C, z. 68, „Statystyka Polski”, Warszawa 1938, s. 37. 
oraz przedstawiciele innych mniejszości narodowych. Generalnie odsetek żołnierzy narodowości polskiej - jak podaje Zygmunt Kubrak - wynosił od 70\% do 90\% ${ }^{149}$.

Pod koniec 1918 r. w Garnizonie Jarosław powołana została Powiatowa Komisja Uzupełnień do przeprowadzania stopniowej demobilizacji roczników 1893-1901. Pobór rekrutów odbywał się na podstawie ustawy 0 powszechnym obowiq̨zku służby wojskowej z dnia 27 października 1918 roku$^{150}$.

Tabela 1. Poborowi do służby w Garnizonie Jarosław z terenu powiatu jarosławskiego wg roczników poboru Powiatowej Komisji Uzupełnień. Stan w dniu 1 września 1920 r.

\begin{tabular}{|c|c|c|c|c|c|c|c|c|c|c|c|c|}
\hline \multirow[t]{2}{*}{ Lp. } & \multirow[t]{2}{*}{ Rok } & \multirow{2}{*}{$\begin{array}{c}\text { Liczba } \\
\text { pobo- } \\
\text { rowych }\end{array}$} & \multicolumn{10}{|c|}{ Wyznanie } \\
\hline & & & $\begin{array}{c}\text { katolickie } \\
\text { obrz. } \\
\text { łaciński }\end{array}$ & $\%$ & $\begin{array}{c}\text { katolickie } \\
\text { obrz. } \\
\text { gr.-kat. }\end{array}$ & $\%$ & $\begin{array}{l}\text { mojże- } \\
\text { szowe }\end{array}$ & $\%$ & $\begin{array}{l}\text { pra- } \\
\text { wo- } \\
\text { sła- } \\
\text { wne }\end{array}$ & $\%$ & inne & $\%$ \\
\hline 1. & 1895 & 152 & 149 & 98 & b.d. & b.d. & b.d. & b.d. & 2 & 1 & 1 & 1 \\
\hline 2. & 1896 & 438 & 357 & 82 & 63 & 14 & 18 & 4 & b.d. & b.d. & b.d. & b.d \\
\hline 3. & 1897 & 483 & 390 & 81 & 56 & 12 & 36 & 8 & b.d. & b.d. & 1 & 1 \\
\hline 4. & 1899 & 616 & 507 & 82 & 69 & 11 & 40 & 7 & b.d. & b.d. & b.d. & b.d \\
\hline 5. & 1900 & 374 & 308 & 82 & 46 & 12 & 20 & 5 & b.d. & b.d. & b.d. & b.d \\
\hline 6. & 1901 & 358 & 304 & 85 & 36 & b.d. & 18 & 10 & b.d. & b.d. & b.d. & b.d \\
\hline 7. & 1902 & 220 & 219 & 99 & 1 & 1 & b.d. & b.d. & b.d. & b.d. & b.d. & b.d \\
\hline
\end{tabular}

b.d. - brak danych

Źródło: WBH. CAW, sygn. I. 300.7.199, Mob. Org. Szt. W. S. Wojsk., Wykaz statystyczny stan w dniu 1/IX 1920.

Najwyższy odsetek, wynoszący od 81\% do 99\% wszystkich poborowych, obejmował wyznanie katolickie obrządku łacińskiego. Drugie miejsce zajmowali grekokatolicy, stanowiąc przedział od $1 \%$ do $14 \%$, natomiast trzecie - od $4 \%$ do $10 \%$ - poborowi wyznania mojżeszowego. Tylko 1\% stanowili poborowi wyznania prawosławnego i innych wyznań.

Najwyższy odsetek, ponad 40\% z ogólnej liczby poborowych stanowili rolnicy. Drugie miejsce - 13\% - to robotnicy, trzecie - 12\% - rzemieślnicy. W dalszej kolejności byli poborowi reprezentujący handel - 4,8\%, następnie reprezentanci innych zawodów - 4,5\% oraz absolwenci szkół średnich - 4\%. Poniżej jednego procenta poborowych stanowili bezrobotni, przedstawiciele wolnych zawodów i służb mundurowych.

\footnotetext{
${ }^{149}$ Z. Kubrak, 24 Dywizja Piechoty..., s. 126-127.

150 „Dziennik Praw Królestwa Polskiego”, nr 13 z 29 X 1918 r. Nowa ustawa O powszechnym obowiązku służby wojskowej uchwalona została przez Sejm RP 23 maja 1924 r. (Dz.U. RP z 1924 r., Nr 61, poz. 580). Patrz: M. Cieplewicz, Wojsko Polskie w latach 1921-1926, Wrocław-Warszawa-Kraków 1998, s. 150.
} 
Jacek Marian Hołub

Tabela 2. Poborowi do służby w Garnizonie Jarosław z terenu powiatu jarosławskiego wg zawodu wykonywanego przed poborem. Stan w dniu 1 września $1920 \mathrm{r}$.

\begin{tabular}{|c|c|c|c|c|c|c|c|c|c|c|}
\hline \multirow{3}{*}{$\begin{array}{l}\text { Lp. } \\
1 .\end{array}$} & \multirow{3}{*}{\begin{tabular}{|c|c}
$\begin{array}{c}\text { Status } \\
\text { zawodowy lub } \\
\text { społeczny* }\end{array}$ \\
wolne zawody \\
\end{tabular}} & \multicolumn{7}{|c|}{ Rocznik poboru } & \multirow{2}{*}{\multicolumn{2}{|c|}{ Razem }} \\
\hline & & \multirow{2}{*}{\begin{tabular}{|c|}
1895 \\
1
\end{tabular}} & \multirow{2}{*}{$\begin{array}{c}1896 \\
2\end{array}$} & \multirow{2}{*}{$\begin{array}{c}1897 \\
4\end{array}$} & \multirow{2}{*}{$\begin{array}{c}1898 \\
2\end{array}$} & \multirow{2}{*}{$\begin{array}{c}1899 \\
\text { b.d. }\end{array}$} & \multirow{2}{*}{$\begin{array}{c}1900 \\
4\end{array}$} & \multirow{2}{*}{$\begin{array}{c}1902 \\
\text { b.d. }\end{array}$} & & \\
\hline & & & & & & & & & 13 & $0,5 \%$ \\
\hline 2. & handlowcy & 1 & 2 & 2 & 76 & 15 & 7 & 3 & 125 & $4,8 \%$ \\
\hline 3. & studenci & 4 & b.d. & 4 & 6 & 3 & 1 & b.d. & 18 & $0,7 \%$ \\
\hline 4. & $\begin{array}{l}\text { absolwenci szkół } \\
\text { średnich }\end{array}$ & 8 & 7 & 10 & 17 & 22 & 26 & 18 & 108 & $4,0 \%$ \\
\hline 5. & rolnicy & 112 & 278 & 307 & 372 & 168 & 161 & 182 & 1580 & $41 \%$ \\
\hline 6. & rzemieślnicy & 6 & 33 & 66 & 80 & 61 & 58 & 4 & 308 & $12 \%$ \\
\hline 7. & robotnicy & 14 & 74 & 59 & 32 & 75 & 88 & 9 & 351 & $13 \%$ \\
\hline 8. & $\begin{array}{l}\text { służby } \\
\text { mundurowe }\end{array}$ & b.d. & b.d. & b.d. & b.d. & b.d. & b.d. & b.d. & 1 & $0,1 \%$ \\
\hline 9. & inne zawody & 4 & 37 & 10 & 31 & 22 & 13 & 1 & 118 & $4,5 \%$ \\
\hline 10. & bez zawodu & 2 & 5 & 4 & b.d. & 8 & b.d. & 2 & 21 & $0,7 \%$ \\
\hline
\end{tabular}

* termin źródłowy

b.d. - brak danych

Źródło: WBH, CAW, sygn. I. 300.7.199, Mob. Org. Szt. W. S. Wojsk., Wykaz statystyczny stan w dniu 1/IX 1920.

Dane z powyższej tabeli wskazują, że 65\% ogólnej liczby poborowych, tj. 1728 osób posiadało wykształcenie domowe i niższe, natomiast najniższy odsetek, bo zaledwie $0,1 \%$, czyli 4 poborowych posiadało wykształcenie wyższe. Co czwarty poborowy był analfabetą lub półanalfabetą, co stanowiło 25\% ogólnej liczby poborowych ${ }^{151}$. Problem ten, z którym służby oświatowe w okresie pokoju musiały się zmierzyć, dotyczył poborowych wszystkich garnizonów Drugiej Rzeczypospolitej.

\section{Życie żołnierzy w garnizonie}

Ważną rolę w wychowaniu żołnierza i obywatela pełniły uroczystości narodowe i wojskowe, m.in. rocznica uchwalenia Konstytucji 3 Maja, święto Odzyskania Niepod-

${ }^{151}$ Według Lecha Wyczelskiego, rozmiar analfabetyzmu w Wojsku Polskim w latach 1912-1926 był znaczny, z tendencją wzrostową. 0 ile w $1921 \mathrm{r}$. szacowano liczbę analfabetów i półanalfabetów na ponad 33 tys. żołnierzy, to w 1924 r. wynosiła ona 100 tys. Przyczyną było przerwanie edukacji przez młodzież w okresie I wojny światowej. Szerzej zob. L. Wyczelski, Od demobilizacji do zamachu majowego. Wojsko Polskie w latach 1921-1926, Warszawa 2007, s. 386. 
Tabela 3. Poborowi do służby w Garnizonie Jarosław z terenu powiatu jarosławskiego wg wykształcenia przed poborem. Stan w dniu 1 września 1920 r.

\begin{tabular}{|c|l|c|c|c|c|c|c|c|c|c|}
\hline & \multirow{2}{*}{ Lp. } & Wykształcenie* & \multicolumn{6}{|c|}{ Rocznik poboru } & \multicolumn{2}{c|}{ Razem } \\
\cline { 2 - 11 } & $\mathbf{1 8 9 5}$ & $\mathbf{1 8 9 6}$ & $\mathbf{1 8 9 7}$ & $\mathbf{1 8 9 9}$ & $\mathbf{1 9 0 0}$ & $\mathbf{1 9 0 1}$ & $\mathbf{1 9 0 1}$ & \multicolumn{2}{c|}{} \\
\hline 1. & analfabeci & 120 & 80 & 104 & 111 & 90 & 84 & 78 & 667 & $25 \%$ \\
\hline 2. & $\begin{array}{l}\text { domowe lub } \\
\text { niższe }\end{array}$ & 68 & 314 & 40 & 522 & 310 & 285 & 189 & 1728 & $65 \%$ \\
\hline 3. & $\begin{array}{l}\text { nieukończone } \\
\text { średnie }\end{array}$ & 6 & 51 & 17 & 20 & 23 & 34 & 15 & 166 & $6,0 \%$ \\
\hline 4. & $\begin{array}{l}\text { ukończone } \\
\text { średnie }\end{array}$ & 2 & 43 & 3 & 12 & 1 & 1 & 3 & 65 & $3,0 \%$ \\
\hline 5. & $\begin{array}{l}\text { nieukończone } \\
\text { wyższe }\end{array}$ & 4 & b.d. & 4 & 1 & b.d. & 4 & b.d. & 13 & $0,5 \%$ \\
\hline 6. & $\begin{array}{l}\text { ukończone } \\
\text { wyższe }\end{array}$ & 2 & b.d. & 2 & b.d. & b.d. & b.d. & b.d. & 4 & $0,1 \%$ \\
\hline
\end{tabular}

*język źródła

b.d. - brak danych

Źródło: WBH, CAW, sygn. I. 300.7.199, Mob. Org. Szt. W. S. Wojsk., Wykaz statystyczny stan w dniu 1/IX 1920.

ległości czy święto Żołnierza Polskiego. Żołnierze Garnizonu Jarosław uczestniczyli obowiązkowo w świętach Kościoła katolickiego obu obrządków, np. w niedzielnych Mszach świętych oraz procesjach teoforycznych ulicami miasta ${ }^{152}$. W nabożeństwach brały udział: kompania reprezentacyjna, orkiestra wojskowa, poczet sztandarowy, żołnierze szeregowi, podoficerowie, korpus oficerski, władze samorządowe oraz katolicy obu obrządków. Z udziału w uroczystościach religijnych zwolnieni byli żołnierze deklarujący inne wyznanie. Żołnierze wyznania mojżeszowego swoje praktyki religijne odbywali w sobotę w Dużej Synagodze. Dla chorych żołnierzy Msza święta niedzielna była odprawiana w kaplicy szpitala wojskowego ${ }^{153}$.

Podniosłą atmosferę w mieście tworzyły święta pułkowe, które obchodzono głównie na terenie koszar. Uroczystości rozpoczynała Msza święta polowa według rytu rzymskiego przy udziale całego pułku. Kapelan Garnizonu Jarosław każdorazowo musiał uzyskać zezwolenie od Kurii Biskupiej Diecezji Przemyskiej na odprawienie Mszy świętej poza terenem koszar ${ }^{154}$. Po Mszy św. odbywała się defilada podod-

${ }^{152}$ Zob. Uroczysta procesja Bożego Ciała; Uroczystość Bożego Ciała: „Express Jarosławski” 1937, nr 8, s. 3. „Tygodnik Jarosławski” 1928, nr 24, s. 2; Tygodnik Jarosławski” 1935, nr 26, s. 2; „Tygodnik Jarosławski” 1934, nr 44, s. 2; „Wiadomości Jarosławskie” 1928, nr 11, s. 4; nr 14, s. 1-2; „Głos Jarosławski” 1927, nr 1, s. 4; „Express Jarosławski” 1928, nr 2, s. 2.

${ }^{153}$ Parafia wojskowa, „Jarosławskie Wiadomości Parafialne” 1929, nr 1, s. 1.

${ }^{154}$ AAPwP, Teczka Jarosław, TPS/88/1, 25 V 1930 r., Prośba ks. W. Pączka kapelana Garnizonu Jarosław, b.p. 
działów, organizowano zawody sportowe i strzeleckie ${ }^{155}$, wspólny obiad żołnierski, rauty w salach Kasyna Garnizonowego oraz zabawę taneczną na wolnym powietrzu z udziałem mieszkańców Jarosławia ${ }^{156}$.

Wyjątkową uroczystością była przysięga młodego rocznika ${ }^{157}$. Święto poprzedzała Msza święta polowa, którą koncelebrowali księża Kościoła katolickiego obu obrządków, w tym kapelani Garnizonu. Na przysięgę zapraszani byli: rabin gminy żydowskiej, pastor zboru ewangelickiego, rodziny żołnierzy, władze samorządowe, wojskowe oraz mieszkańcy Jarosławia ${ }^{158}$.

15 sierpnia obchodzone było Święto Żołnierza Polskiego ${ }^{159}$, które poprzedzał capstrzyk z udziałem orkiestry wojskowej i jej przemarsz ulicami miasta. Uroczystość rozpoczynała Msza świętej w kościele parafialnym, sprawowana w intencji Ojczyzny przez kler parafialny i kapelanów Garnizonu ${ }^{160}$. Później na Rynku odbywała się defilada wojsk Garnizonu Jarosław, a następnie okolicznościowa akademia w sali Towarzystwa Gimnastycznego „Sokół”. Na zakończenie organizowano bezpłatną plenerową zabawę taneczną dla żołnierzy i ludności cywilnej ${ }^{161}$.

Jedną z najpopularniejszych rozrywek żołnierzy był udział w projekcjach filmowych trzech jarosławskich kin. Zarządzający placówkami, po konsultacjach z oficerami oświatowymi Komendy Garnizonu, dostosowywali repertuar do potrzeb wojska. Ponadto żołnierze oglądali spektakle i akademie oraz uczestniczyli w odczytach, wykładach i prelekcjach.

Żołnierze Garnizonu Jarosław, podobnie jak społeczność cywilna miasta, obchodzili w latach 1928-1935 imieniny Józefa Piłsudskiego (19 marca) ${ }^{162}$, a od 1936 r. do wybuchu II wojny światowej - rocznicę jego śmierci, biorąc udział w nabożeństwach odprawianych we wszystkich świątyniach katolickich, zborze ewangelickim i w synagodze ${ }^{163}$.

${ }^{155}$ Zawody strzeleckie 3 pp. leg., „Tygodnik Jarosławski” 1928, nr 39, s. 3; Kronika sportowa: Polonia : Trzeciak (K.S. 2 pp. leg.), „Ziemia Przemyska” 1927, nr 41, s. 4.

156 Święto pułkowe 3 pp. Legionów, „Głos Jarosławski” 1927, nr 6, s. 3; Święto pułkowe, „Głos Jarosławski” 1928, nr 38, s. 3; Święto pułkowe sympatycznego 3 pułku łączności, „Tygodnik Jarosławski" 1928, nr 25, s. 2.

157 Przysięga rekruta na placu koszar, „Ziemia Rzeszowska i Jarosławska” 1924, nr 50, s. 3.

${ }^{158}$ Przysięga rekrutów, „Ziemia Rzeszowska i Jarosławska” 1924, nr 50, s. 4.

${ }^{159}$ Święto związane było z rocznicą zwycięskiej Bitwy Warszawskiej 15 VIII 1920 r., tzw. Cudu nad Wisłą. Ustanowienie Święta Żołnierza sankcjonował rozkaz Ministra Spraw Wojskowych gen. broni Stanisława Szeptyckiego nr 126 z dnia 4 sierpnia 1923 r.

${ }^{160}$ APP, AmJ, sygn. 565, Kultura i oświata, k. 135; Święto Żołnierza Polskiego. Program święta, k. 491. Patrz: Narodowy „Cud nad Wisłą” $i$ sanacyjny „Cud nad Wieprzem”, „Głos Jarosławski” 1930, nr 33, s. 1; „Cud Wisły” - świętem endecji, „Głos Jarosławski” 1930, nr 34, s. 2-3; Uroczystości 12-lecia Cudu nad Wisła, „Głos Jarosławski” 1932, nr 34, s. 2; Na Święto Żołnierza, „Gazeta Jarosławska” 1937, nr 32, s. 1.

${ }^{161}$ Święto całego Narodu, „Gazeta Jarosławska” 1936, nr 33, s. 1; Inicjatywa powiatowego komitetu, „Gazeta Jarosławska” 1936, nr 33, s. 3.

162 Poranek ku czci imienia Marszałka Piłsudskiego, „Gazeta Jarosławska” 1930, nr 12, s. 2; Wodzowi Narodu, „Gazeta Jarosławska” 1935, nr 6, s. 1-2; W hołdzie pamięci Marszałka Piłsudskiego, „Gazeta Jarosławska” 1938, nr 13, s. 3.

${ }^{163}$ Jarosław Marszałkowi w hołdzie, „Gazeta Jarosławska” 1935, nr 6, s. 1; Uroczystości żałobne w szkołach w rocznicę zgonu Marszałka Piłsudskiego, „Express Jarosławski” 1937, nr 4, s. 1; APP, AmJ, sygn. 682, Ogłoszenia. Nekrolog w I rocznicę śmierci Marszałka Józefa Piłsudskiego. 


\section{Wojsko w życiu miasta}

Władze Garnizonu Jarosław organizowały lub współorganizowały na terenie miasta szereg uroczystości o zasięgu państwowym i lokalnym. Rocznica uchwalenia Konstytucji 3 Maja ${ }^{164}$ była współorganizowana przez Gminę Miejską w Jarosławiu i Komendę Garnizonu Jarosław ${ }^{165}$. Świętem podkreślającym poczucie wolności była rocznica Odzyskania Niepodległości przypadająca w dniu 11 listopada ${ }^{166}$. W Jarosławiu uroczystość organizowana była przez parafię rzymskokatolicką, Gminę Miejską i Komendę Garnizonu Jarosław. Scenariusz uwzględniał poranne nabożeństwo dziękczynne w intencji Ojczyzny w kościele parafialnym, cerkwi greckokatolickiej oraz w Dużej Synagodze ${ }^{167}$.

Po śmierci Marszałka Polski Józefa Piłsudskiego odprawiono w Jarosławiu nabożeństwo żałobne z egzekwiami. Uroczystości odbyły się 17 maja 1935 r. na Stadionie Wojskowym z udziałem mieszkańców miasta ${ }^{168}$. Organizatorem był Burmistrz Miasta Jarosławia wraz z Komendantem Garnizonu Jarosław ${ }^{169}$.

W parku miejskim cyklicznie koncertowały wojskowe orkiestry dęte, m.in. 3. Pułku Legionów oraz 39. Pułku Strzelców Lwowskich. Popisy te spotykały się z dużą przychylnością ze strony mieszkańców Jarosławia. Udział w darmowych koncertach stał się szczególnym sposobem popularyzacji muzyki oraz ucztą duchową dla słuchających.

W ramach rozwoju sportu w Jarosławiu władze Garnizonu zakupiły od Towarzystwa Gimnastycznego „Sokół” stadion sportowy przy ul. Słowackiego, z nowoczesną płytą boiska piłkarskiego, bieżnią oraz trybuną. Obiekt dostępny był także dla ludności cywilnej do zawodów sportowych, jak i lokalnych uroczystości ${ }^{170}$.

Żołnierze garnizonu, na rozkaz gen. brygady Wacława Scaewoli-Wieczorkiewicza, uruchomili w okresie zimowym 1936/1937 akcję pomocy bezrobotnym i biednym. Podoficerowie zorganizowali zbiórkę odzieży i żywności oraz przygotowali paczki świąteczne dla dzieci. Dodatkowo przekazano z zapasów magazynowych ponad 1000 kg ziarna na zasiew dla ubogich rolników ${ }^{171}$.

Żołnierze nieśli też pomoc ludności cywilnej na Przedmieściu Dolnoleżajskim w czasie klęski żywiołowej, jaką był wylew rzeki San podczas roztopów wiosen-

164 Obchodzenie rocznicy uchwalenia Konstytucji z 1791 r. zostało uznane za święto państwowe (narodowe) Uchwałą Sejmu Ustawodawczego z dnia 29 kwietnia 1919 r. Ustawa $O$ święcie narodowym trzeciego maja (Dz. Pr. PP. z 1919 r., Nr 38, poz. 281).

165 Obchód konstytucji 3-go maja, „Gazeta Jarosławska” 1934, nr 8, s. 5; Święto Narodowe 3-go maja, „Tygodnik Jarosławski”1932, nr 19, s. 1.

${ }^{166}$ Święto Odzyskania Niepodległości zostało wprowadzone przez Sejm Rzeczypospolitej 23 kwietnia 1937 r. Ustawa O Święcie Niepodległości, (Dz.U. RP z 1937 r., Nr 33, poz. 255).

167 Obywatele!, „Głos Jarosławski” 1928, nr 44, s. 1; Obchód Święta 11 rocznicy Niepodległości Polski, „Express Jarosławski” 1929, nr 46, s. 2.

${ }^{168}$ Nabożeństwo żałobne na stadionie, „Gazeta Jarosławska” 1935, nr 11, s. 2.

169 Przemówienie na zgon Marszałka Józefa Piłsudskiego, „Gazeta Jarosławska” 1935, nr 12, s. 1-3; „Ojczyzny nieśmiertelnej serce wielkie bić przestało”, „Gazeta Jarosławska” 1935, nr 20, s. 1; Z. Kostka-Bieńkowska, Między wojnami, [w:] Jarosławskie przemiany, red. Ł. Zagrobelny, Jarosław 2018, s. 132-133; M. Gałęzowski, A. Przewoźnik, Gdy wódz odchodził w wieczność... Uroczystości żałobne po śmieci Marszałka Józefa Piłsudskiego 12-18 maja 1935 r., Warszawa 2005, s. 212; Jarosławskie przemiany..., s. 136-137.

${ }^{170}$ DALO, F. 1, op. 54, spr. 4013, Wojskowy Klub Sportowy „Trzeciak” przy 3 pp. Legionów, passim.

${ }^{171}$ Garnizon jarosławski bezrobotnym, „Express Jarosławski” 1937, nr 5, s. 3. 


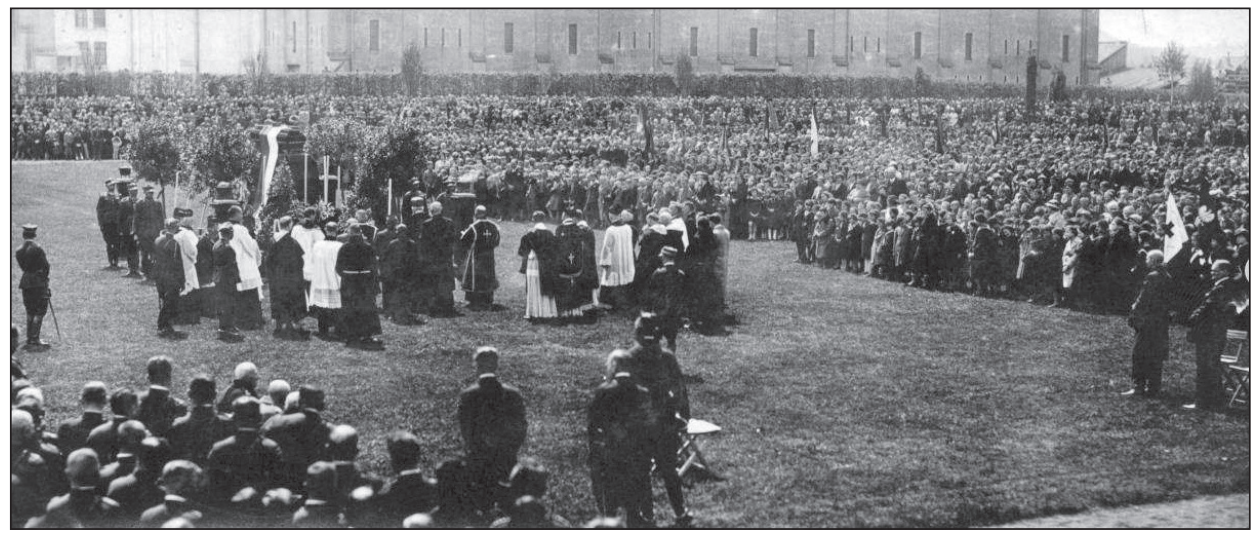

Fot. 6. Nabożeństwo żałobne na stadionie Wojskowo-Cywilnego Klubu Sportowego „Ognisko” po śmierci Marszałka Polski Józefa Piłsudskiego. Jarosław, 17 maja 1935 r. (źródło: Muzeum w Jarosławiu Kamienica Orsettich).

nych. Dodatkowo, wojskowa straż pożarna wspierała działania ratowniczo-gaśnicze miejskiej jednostki pożarniczej, np. w 1929 r. w walce z pożarem poddasza dwupiętrowej kamienicy Żyda Juliusza Strisowera przy ul. Grunwaldzkiej ${ }^{172}$.

Wyrazem solidarności mieszkańców z wojskiem było manifestacyjne witanie na ulicach miasta żołnierzy powracających z ćwiczeń do Garnizonu ${ }^{173}$ :

[...] Maszerując głównymi ulicami naszego grodu, przy dźwiękach doskonałej orkiestry, oddział prezentował się wzorowo i był mile widziany przez mieszkańców miasta, którzy tłumnie zjawili się na powitanie ${ }^{174}$.

Ważną rolę dla funkcjonowania Garnizonu pełniły zakładane przez jarosławian spółki cywilne, które dostarczały płody rolne i dostawy kontraktowe do Kwatermistrzostwa Garnizonu. Zaopatrzenie w produkty spożywcze i płody rolne zapewniała także m.in. Składnica Kółek Rolniczych ${ }^{175}$ oraz Spółka Zdemobilizowanych Oficerów ${ }^{176}$.

Mieszkańcy Jarosławia byli również świadkami negatywnych zachowań żołnierzy, którym zdarzało się naruszać dyscyplinę wojskową i zakłócać porządek publiczny. Dotyczyło to incydentów i awantur wywoływanych przez oficerów w lokalach publicznych. 0 przypadkach samobójstwa czy zabójstwa przy użyciu broni służbo-

172 Pożar w kamienicy Strisowera, „Głos Jarosławski” 1929, nr 21, s. 2; Olbrzymi pożar na pryncypialnej ulicy, „Express Jarosławski” 1929, nr 21, s. 2-3.

${ }^{173}$ Z Pełkiń, „Gazeta Jarosławska” 1937, nr 37, s. 3; W. Kielar, I nasze młode..., s. 178.

${ }^{174}$ Wrócili z kilkudniowych manewrów do naszego grodu, „Tygodnik Jarosławski” 1928, nr 37, s. 3; Z manewrów wrócił 3. pp. Leg., „Tygodnik Jarosławski” 1928, nr 39, s. 3.

175 Dostawa wojskowa a Żydzi, „Ziemia Rzeszowska i Jarosławska” 1924, nr 26, s. 4.

${ }^{176}$ Dostawy wojskowe, „Ziemia Rzeszowska i Jarosławska” 1924, nr 5, s. 3-4. 
wej informowała lokalna prasa ${ }^{177}$ - np. zabójstwo kpt. Stanisława Szafrana ${ }^{178}$ czy śmierć st. sierż. Alfreda Bittmana ${ }^{179}$.

\section{Zakończenie}

Obecność garnizonu wojskowego w Jarosławiu od końca XVIII stulecia do 1939 r. wpływała stymulująco na rozwój miasta. Liczna załoga wielkonarodowego i wielowyznaniowego garnizonu wpisała się znacząco w rozkwit gospodarczy, społeczny, kulturalny i sportowy Jarosławia. Z obecności wojska w okresie pokoju korzystali mieszkańcy miasta i okolic, prowadząc działalność gospodarczą oraz wykonując usługi na rzecz garnizonu i żołnierzy. Wojsko zapewniało społeczności miejskiej bezpieczeństwo i oddziaływało dynamizująco także na inne sfery życia.

Dzięki rozbudowie garnizonu wojskowego w okresie autonomii galicyjskiej do 1914 r. miasto znacznie powiększyło granice administracyjne, gdyż w obszarze przedmieść oraz wytyczonych dzielnic powstały obiekty militarne oraz rozwinęła się infrastruktura miejska i budownictwo jednorodzinne. Rozwój infrastruktury koszar wojskowych oraz duża liczba wojska miały wpływ na dynamiczny rozwój usług budowlanych, hotelarskich i gastronomicznych.

Okres I wojny światowej odznaczył się dla austriackiego garnizonu dyspozycją oddziałów wojskowych w obronie miasta i jego mieszkańców. Jednak dwukrotna inwazja wojsk rosyjskich oraz przesuwający się front wojenny, w tym zaciekłe walki pod Jarosławiem, spowodowały duże zniszczenia w mieście i okolicznych miejscowościach.

W okresie dwudziestolecia międzywojennego, kiedy w garnizonie stacjonowały w zdecydowanej większości oddziały składające się z polskich żołnierzy, kontynuowano tradycje pokojowe stacjonujących tu różnych formacji wojskowych. Skoszarowane na terenie miasta wojsko wykonywało zadania szkoleniowe przypadające na okres pokoju na wielu płaszczyznach. Ważnym elementem integracji żołnierzy z cywilną częścią społeczeństwa w Jarosławiu była rywalizacja sportowa, uczestnictwo

${ }^{177}$ L. Wyczelski, Od demobilizacji do zamachu..., s. 254; Samobójstwo szeregowca..., „Tygodnik Jarosławski” 1928, nr 8, s. 3; Samobójstwo żołnierza-żyda, „Tygodnik Jarosławski” 1928, nr 39, s. 3; Samobójstwo szeregowego 3 pp. Leg., „Głos Jarosławski” 1928, nr 10, s. 3, Nieszczęśliwe wypadki, „Głos Jarosławski” 1928, nr 38, s. 4; Samobójstwo żołnierza, „Express Jarosławski” nr 3, s. 3; Samobójstwo pod kołami pociagu pośpiesznego, „Express Jarosławski” 1929, nr 44, s. 3; Usiłowane samobójstwo, „Express Jarosławski” 1929, nr 46, s. 3.

178 Strzelanina na ul. Słowackiego, „Express Jarosławski” 1928, nr 7, s. 3; Morderstwo, „Tygodnik Jarosławski” 1929, nr 45, s. 4; Kronika policyjna. „Głos Jarosławski” 1929, nr 45, s. 3; Epilog tragicznej zabawy przed sądem wojskowym, „Express Jarosławski” 1930, nr 15, s. 3; Kronika, „Tygodnik Jarosławski” 1930, nr 22, s. 1-2; Z procesu por. Nowotnego, „Tygodnik Jarosławski” 1930, nr 26, s. 2; Tragedia małżeńska, „Głos Jarosławski” 1930, nr 27, s. 2; Głośna sprawa zabójstwa śp. kapitana Szafrana przez Nowotnego, „Głos Jarosławski” 1930, nr 30, s. 4.

${ }^{179}$ Alfred Bittman - ur. 11 XII 1899 r. w Uzara w Bośni. Żołnierz Wojska Polskiego, starszy sierżant 2. Pułku Łączności w Jarosławiu. Szef I kompanii. Zginął od wybuchu granatu na placu ćwiczeń 26 III 1928 r. Pochowany na Starym Cmentarzu w Jarosławiu. 
w uroczystościach państwowych i religijnych. Służba w jednostkach wojskowych wpływła na wzrost poczucia bezpieczeństwa, a niejednokrotnie rozkazy wojskowe umożliwiały wsparcie materialne jarosławian podczas klęsk żywiołowych.

W okresie międzywojennym kadra oficerska angażowała się w działalność statutową w organizacjach społecznych, sportowych, oświatowych i kulturalnych. Część oficerów pełniła społeczne funkcje w zarządach organizacji wojskowych i cywilnych, które pobudzały aktywność mieszkańców czy budowały lokalną tożsamość społeczną.

Reasumując, należy pozytywnie ocenić działalność garnizonu wojskowego na przestrzeni ponad 150 lat jego istnienia w Jarosławiu w stosunku do mieszkańców i władz miasta.

\section{Wykaz wykorzystanych źródeł archiwalnych, źródeł drukowanych, relacji, opracowań i źródeł internetowych}

\section{Źródła archiwalne:}

Archiwum Archidiecezji Przemyskiej w Przemyślu (AAPwP). Archiwum Fabryki Ciastek Modelez w Jarosławiu (AFCMwJ). Archiwum Narodowe w Krakowie (ANwK). Archiwum Państwowe w Przemyślu (APP). Archiwum Parafii Bożego Ciała w Jarosławiu im. Księdza Jakuba Makary (APBCwJ). Derżawnyj Archiw Lwiwśkoji Obłasti (DALO). Muzeum w Jarosławiu Kamienica Orsettich (MwJKO).

Wojskowe Biuro Historyczne im. gen. broni Bolesława Sosnkowskiego.

\section{Zbiory prywatne:}

Zbiory Jerzego Czechowicza.

\section{Źródła drukowane:}

Konkordat pomiędzy Stolicą Apostolskq a Rzeczqpospolitą Polskq, podpisany w Rzymie dnia 10 lutego 1925 r. ratyfikowany zgodnie z ustawa z dnia 23 kwietnia 1925 r. (Dz.U. RP z 1925 r., Nr 47, poz. 324, Nr 72, poz. 501).

\section{Źródła statystyczne:}

Drugi powszechny spis ludności z dnia 9 grudnia 1931 roku. Mieszkania i gospodarstwa domowe. Ludność. Stosunki zawodowe: Województwo Lwowskie bez miasta Lwowa, seria C, z. 68, „Statystyka Polski”, Warszawa 1938.

Skorowidz gmin Rzeczypospolitej Polskiej i ludności i budynków na podstawie tymczasowych wyników drugiego Powszechnego Spisu Ludności z dnia 9 grudnia 1931 r. oraz powierzchnia ogólna, cz. III a: Województwa południowe, Warszawa 1935. 
pierwszego powszechnego spisu ludności z dn. 30 września 1921 r. i innych źródeł urzędowych, t. XIII: Woj. Lwowskie, Warszawa 1924.

Wiadomości statystyczne o stosunkach krajowych. Najważniejsze wyniki spisu ludności i zwierząt domowych według stanu z dn. 31 grudnia 1910 r., red. T. Pilat, t. XXIV, z. 1, Lwów 1911.

Zamorski K., Informator statystyczny do dziejów społeczno-gospodarczych Galicji: ludność Galicji w latach 1857-1910, red. H. Mandurowicz-Urbańska, Kraków-Warszawa 1989.

\section{Pamiętniki, wspomnienia i dzienniki:}

Buczyński E., Smutny wrzesień, Kraków 1985.

Csàdek J., „Z wojny narodowej 1918-1920 r.”. Wspomnienia z niektórych walk i przeżyć 14-go jarosławskiego pułku piechoty względnie 4-tej dywizji piechoty, t. I, Lwów 1935.

Kielar W., I nasze młode lata, Wrocław 1987.

\section{Prasa i czasopisma:}

„Chwila” (wydanie wieczorne) [Lwów] 1937-1939.

„Express Jarosławski” 1928-1939.

„Gazeta Jarosławska” 1935-1938.

„Głos Jarosławski” 1919, 1927-1932.

„Jarosławskie Wiadomości Parafialne” 1929-1939.

„Kronika Diecezji Przemyskiej” 1938.

„Polska Zbrojna” 1925.

„Tygodnik Jarosławski” 1918-1939.

„Wiadomości Jarosławskie” 1928.

„Ziemia Przemyska” 1927.

„Ziemia Rzeszowska i Jarosławska” 1924.

\section{Źródła ikonograficzne:}

Zbiór fotografii Muzeum w Jarosławiu Kamienica Orsettich.

\section{Opracowania:}

Adamik S., Kronika Szpitala psychiatrycznego w Jarosławiu. 60 lat działalności, Jarosław 2014.

Bechta G., Konferencja - Jarosław 24.06.2015 r. [w:] Służba wojskowa w garnizonach jarosławskim i przemyskim „wczoraj i dziś”, red. G. Bechta, S. Nabywaniec, T. Skupień, Rzeszów 2016.

Białynia J., Chołodecki J., Kilka szczegółów z przeszłości miasta Jarosławia, „Rocznik Stowarzyszenia Miłośników Jarosławia”, t. XII, 1986-1993, Jarosław 1994.

Bielanowicz Z., Rezydencja biskupów przemyskich w Radymnie, „Rocznik Stowarzyszenia Miłośników Jarosławia”, t. XI, 1984-1985, Jarosław 1986.

Borcz H., Dekanat Jarosławski w II Rzeczypospolitej $i$ w latach II wojny światowej (1918-1945) [w:] Sługa Boży ksiądz Stanisław Sudoł, zwiastun pojednania i dobroci, red. J. Konefał, Sandomierz 2015. 
Cieplewicz M., Wojsko Polskie w latach 1921-1926, Wrocław 1998.

Dalecki R., Jarosławski 39 Pułk Piechoty Strzelców Lwowskich w działaniach wojennych 1939 r., „Rocznik Przemyski” 1983, t. XXII-XXIII, Przemyśl 1983.

Demkowicz-Dobrzański M., Legenda czy prawda o grobie hetmana Karola Chodkiewicza w Jarosławiu w świetle historycznych badań, Jarosław 1937.

Gałęzowski M., Przewoźnik A., Gdy wódz odchodził w wieczność... Uroczystości żałobne po śmieci Marszałka Józefa Piłsudskiego 12-18 maja 1935 r., Warszawa 2005.

Gosztyła M., Jagieła B., Dudzik I., Architektura Galicji w dobie autonomii na przykładzie Jarosławia, Rzeszów 2013.

Gottfried K., Jarosław. Dzieje miasta od jego początków do 1939 roku, Jarosław 2019.

Hołub J., Dawne kolegium oo. Jezuitów. Kolegiata Bożego Ciała w Jarosławiu, Jarosław 2004.

Hołub J., Dawne Opactwo PP. Benedyktynek. Ośrodek Kultury i Formacji Chrześcijańskiej im. Sługi Bożej Anny Jenke w Jarosławiu, Jarosław 1999.

Hołub J., Kościół Świętego Ducha w Jarosławiu, Jarosław 2007.

Hołub J.M., „Wzgórze pobożności”. Sanktuarium Matki Bożej Bolesnej w Jarosławiu, Jarosław 2017.

Jarosławskie drogi do Niepodległej, red. Ł. Zagrobelny, Jarosław 2018.

Jedliński W., Młodzież Gimnazjum I. w walkach o Niepodległość, [w:] Księga pamiątkowa poświęcona zjazdowi jubileuszowemu z okazji 50-lecia istnienia Gimnazjum I. w Jarosławiu 1884-1934, red. S. Kopystyński, A. Zych, Jarosław 1934.

Kieferling K., Krótka opowieść o mieście Jarosławiu w województwie podkarpackim leżq̨cym, Jarosław 2011.

Kostka-Bieńkowska Z., Jarosławskie CORSO. Historia ulicy Grunwaldzkiej i Krakowskiej, Jarosław 2016.

Kostka-Bieńkowska Z., Między wojnami [w:] Jarosławskie przemiany, red. Ł. Zagrobelny, Jarosław 2018.

Kostka-Bieńkowska Z., Monografia Stowarzyszenia Miłośników Jarosławia, Jarosław 2014.

Księga pamiątkowa poświęcona zjazdowi jubileuszowemu z okazji 50-lecia istnienia Gimnazjum I w Jarosławiu 1884-1934, red. S. Kopystyński, A. Zych, Jarosław 1934.

Kubrak Z., 24 Dywizja Piechoty. Zarys organizacji, uzbrojenie i wyszkolenie piechoty dywizyjnej (1921-1939), „Przemyskie Zapiski Historyczne” 1991-1992, t. 8-9, Przemyśl 1993.

Kubrak Z., Zarys historii wojennej pułków polskich w kampanii wrześniowej. 39 pułk piechoty, Pruszków 1999.

Lisiński M., Noc przełomowa z 31 X na 1 XI 1918 w Jarosławiu, Jarosław 1938.

Majka J., Generał brygady Wacław Scaewola-Wieczorkiewicz 1890-1969. Krótka biografia wojskowa, Rzeszów 2018.

Malczewski J., Wpływ funkcji garnizonowej i inwestycji wojskowych na rozwój miast [w:] Rozwój przestrzenny miast galicyjskich położonych między Dunajcem a Sanem w okresie autonomii galicyjskiej. Materiały z sesji, Jasło 23-24 kwietnia 1999, red. Z. Beiersdorf, A. Laskowski, Jasło 2001.

Nizieński B., Garnizon Wojska Polskiego w Jarosławiu w przededniu wybuchu II wojny światowej, „Rocznik Stowarzyszenia Miłośników Jarosławia”, t. XVIII, 2009-2010, Jarosław 2010.

Odziemkowski J., Armia i społeczeństwo II Rzeczypospolitej, Warszawa 1996.

Odziemkowski J., Frątczak S., Polskie duszpasterstwo wojskowe, Warszawa 1996. 
Orłowicz M., Ilustrowany Przewodnik po Galicji, Bukowinie, Spiszu, Orawie i Śląsku Cieszyńskim, Lwów 1914.

Orłowicz M., Jarosław, jego przeszłość i zabytki, Lwów-Warszawa 1921.

Orłowicz M., Moje wspomnienia turystyczne, Wrocław-Warszawa-Kraków 1970.

Pasterski M., Działalność narodowa i niepodległościowa w Jarosławiu w latach 1900-1918, „Materiały i Studia Muzealne”, t. V, Przemyśl 1982.

Płocica E., 24 Pułk Artylerii Polowej w Jarosławiu, „Rocznik Stowarzyszenia Miłośników Jarosławia", t. XIII, 1994-1999, Jarosław 2000.

Podgórski W.J., Dlaczego Michał Zieliński nie podbił Warszawy, „Rocznik Stowarzyszenia Miłośników Jarosławia”, t. XX, 2013-2014, Jarosław 2014.

Rogala W., Monografia Wojskowej Komendy Uzupełnień w Jarosławiu 1944-2014, Jarosław 2014.

[Setna] 100 rocznica wybuchu I wojny światowej w artyleryjskim Garnizonie Jarosław. Historia, doświadczenie i rozwój artylerii do działań w środowisku górskim, red. G. Bechta, S. Nabywaniec, S. Skupień, Rzeszów 2014.

Skarbowski K., Jarosław i Rok 1918, „Rocznik Stowarzyszenia Miłośników Jarosławia” t. VII, 1967-1968, Jarosław 1968.

Skupień T., Gen. bryg. Wacław Wieczorkiewicz patron 14 DAS [w:] Służba wojskowa w garnizonach jarosławskim i przemyskim „wczoraj i dziś”, red. G. Bechta, S. Nabywaniec, S. Skupień, Rzeszów 2016.

Słota D., Garnizon Jarosław 1934-1939 [w:] Służba wojskowa w garnizonach jarosławskim i przemyskim „Wczoraj i dziś”, Rzeszów 2016.

Służba wojskowa w garnizonach jarosławskim i przemyskim „wczoraj i dziś”, red. G. Bechta, S. Nabywaniec, T. Skupień, Rzeszów 2016.

Smotrecki H., Zarys historii wojennej pułków polskich 1918-1920. 39 Pułk Strzelców Lwowskich, Warszawa 1929.

Sobocki S., Jednostki Garnizonu WP Jarosław, „Rocznik Stowarzyszenia Miłośników Jarosławia”, t. XII, 1986-1993, Jarosław 1994.

Sobocki S., Szpitale II Rzeczypospolitej. Szpital Wojskowy w Jarosławiu, „Rocznik Stowarzyszenia Miłośników Jarosławia”, t. XIX, Jarosław 2011-2012.

Stawecki P., Oficerowie dyplomowani Wojska Drugiej Rzeczypospolitej, Wrocław-Warszawa-Kraków 1997.

Stawecki P., Wojsko Marszałka Józefa Piłsudskiego 12 V 1926 - 12 V 1935, Warszawa 2004.

Stęchły J., Zagospodarowanie przestrzenne Wzgórza Świętego Mikołaja w Jarosławiu w latach 1782-1914, „Ochrona Zabytków” 2013, r. LXVI, nr 1-4(260-263).

Wondaś A., Szkice do dziejów Jarosławia, t. I, Jarosław 1934, t. II, Jarosław 1936.

Wondaś A., Szkice do dziejów Jarosławia, Szkic uzupełniający, Jarosław 1938.

Wyczelski L., Od demobilizacji do zamachu majowego. Wojsko Polskie $w$ latach 1921-1926, Warszawa 2007.

Wysocki W.J., Żak A.Cz., Biskup Władysław Bandurski, Pruszków 1997.

Zieliński J.P., Nasza dola w Jarosławiu, Lwów 1914.

Zieliński M., Serce w plecaku... bije nadal, Jarosław 2013.

Zięba Z., Jarosławskie cmentarze, Jarosław 2008.

Zych S., Diecezja Przemyska obrządku łacińskiego w latach 1939-1944/1945, Przemyśl 2011. 


\section{Abstract}

\section{Military Garrison in Jaroslaw in 1782-1939}

The study concerns the activities of the military in the garrison operating in the urban space of Jaroslaw in the years 1782-1939. This subject has not been of interest to historians and researchers of the history of Jaroslaw so far. The preserved archival sources as well as journalistic material were used to locate the barracks, recreating the organizational structure of divisions and subdivisions, weapons used, a list of barracks personnel, army's activities during peace and war, the day to day life of soldiers in the barracks, as well as their cooperation with the civilian population in Jaroslaw.

\section{Keywords:}

Military garrison, Austrian army, Polish army, Jaroslaw, Galician autonomy period, interwar period. 